\title{
The Financial Crisis and U.S. Cross-Border Financial Flows
}

Carol C. Bertaut and Laurie Pounder, of the Board's Division of International Finance, prepared this article. James Coonan provided research assistance.

This article examines the effects of the recent financial crisis, which began in August 2007, on U.S. financial flows. Cross-border financial flows are of interest for several reasons, including the information they provide about changes in a country's indebtedness, foreign investor attitudes toward domestic assets, and the current account balance. Cross-border financial flows are the counterparts to transactions recorded in the current account, the broadest measure of a country's transactions with the rest of the world. When a country runs a deficit in the current account - as has been the case for the United States since the early 1990s - this imbalance implies that foreign investors must, on net, be acquiring the country's assets. In essence, the United States has been borrowing from the rest of the world to finance the excess of imports over exports. ${ }^{1}$ Foreigners' willingness to continue investing in the United States, and the nature of those investments, determines the price that the United States must pay to continue running current account deficits.

U.S. financial inflows typically occur through foreign purchases of U.S. securities, net lending to U.S. banks and other firms, and foreign direct investment in the United States. During the financial crisis, however, the composition of inflows changed dramatically, and some inflows came from unusual sources.

In this article, we focus on cross-border flows in securities - both foreign purchases of U.S. securities and U.S. purchases of foreign securities - as well as on cross-border bank flows to characterize the effect of the crisis on net inflows. In addition to flows, we analyze the (related) influence of the crisis on gross cross-border securities, banking, and nonbank

1. Alternatively, one could argue that the desire of the rest of the world to invest in the United States causes an imbalance that drives the U.S. current account to be in deficit. positions. ${ }^{2}$ These positions are primary components of the net international investment position of the United States, which measures the country's international financial indebtedness. We identify three major channels through which cross-border flows and positions were affected by the crisis:

1. "flight to safety" shifts in portfolio composition away from riskier securities and toward investments in safe and liquid markets, particularly U.S. Treasury securities ${ }^{3}$

2. unusual flows through the banking system resulting from a shortage of dollar liquidity abroad and the breakdown in interbank markets

3. a pullback from cross-border positions during the financial crisis, reflecting a general increase in risk aversion. We find that although both U.S. and foreign investors did reduce their holdings of cross-border securities and foreign deposits, the adjustments in cross-border portfolio holdings were relatively minor compared with the substantial valuation losses that investors faced. We find somewhat more evidence of such a pullback in banks' own cross-border positions.

These channels, of course, interact in their effects on financial flows and portfolio positions. Flight-tosafety concerns over foreign exposure can result in reduced cross-border positions, and risk aversion can intensify funding pressures.

The first section of the article addresses the flightto-safety flows of private investors out of risky securities and toward U.S. Treasury securities, as well as the shift by official investors to an even heavier concentration of their purchases in U.S. Treasury securities. This section also discusses the unusual flows resulting from the flight of U.S. investors out of foreign securities. Before the crisis, financial inflows from foreign investors were typically partially offset by outflows from U.S. purchases of foreign securities. During the crisis, these flows reversed.

2. We discuss only certain positions of nonbank firms. In particular, we exclude direct investment positions.

3. For the purposes of this article, "Treasury securities" refers to U.S. Treasury securities. 
The second section of the article describes the unusual net lending flows from the United States to Europe - through interbank markets and through liquidity swap lines with the Federal Reserve-in response to a shortage of dollar liquidity abroad. This section breaks the crisis into three distinct phases. During the first phase, covering the first year of the crisis, the majority of banking offices directed lending to the home region of the parent bank. The second phase, the most intense period of the crisis, can be characterized by a breakdown of interbank markets and cross-border borrowing of foreign central banks from the Federal Reserve. Finally, the third phase is the slow recovery of interbank markets in 2009. The analysis disaggregates total net lending by nationality of the parent bank and aggregates individual banklevel data by banks' lending behavior.

While the first two sections discuss net flows for specific sectors of the financial account, the third section documents declines in gross cross-border positions and a slowdown in cross-border trading during the crisis across most instrument types associated with the financial account (including securities, interbank lending, borrowing and lending by nonbank firms, and trade credit). This section shows that the retreat from securities positions during the crisis has been minor, but that banking and other positions have experienced more-significant drops.

The final section concludes, adding a discussion of other countries' experiences of flight to safety and declining cross-border positions during the crisis. The article also includes two boxes. The first box provides background on the data collected by the Treasury International Capital (TIC) reporting system and on the challenges that the crisis presented to the measurement of financial transactions and cross-border portfolio positions (see box "The Treasury International Capital Data Reporting System"). For example, bankruptcy filings, takeovers, and the transition of some financial firms to bank holding company status generated changes that made it difficult to assess whether financial flows were being correctly reported. The second box, "Difficulties in Assessing Market Values of Securities during the Financial Turmoil," discusses the problems inherent in determining the market values of some cross-border securities positions when trading becomes extremely thin.

\section{FLIGHT-TO-SAFETY SHIFTS IN PORTFOLIOS DURING THE CRISIS}

In recent years before the crisis, most of the inflows to the United States occurred through foreign acquisitions of U.S. securities. These foreign acquisitions,
1. Foreign net purchases of U.S. securities, by type of purchaser, and U.S. current account deficit, 2002-09

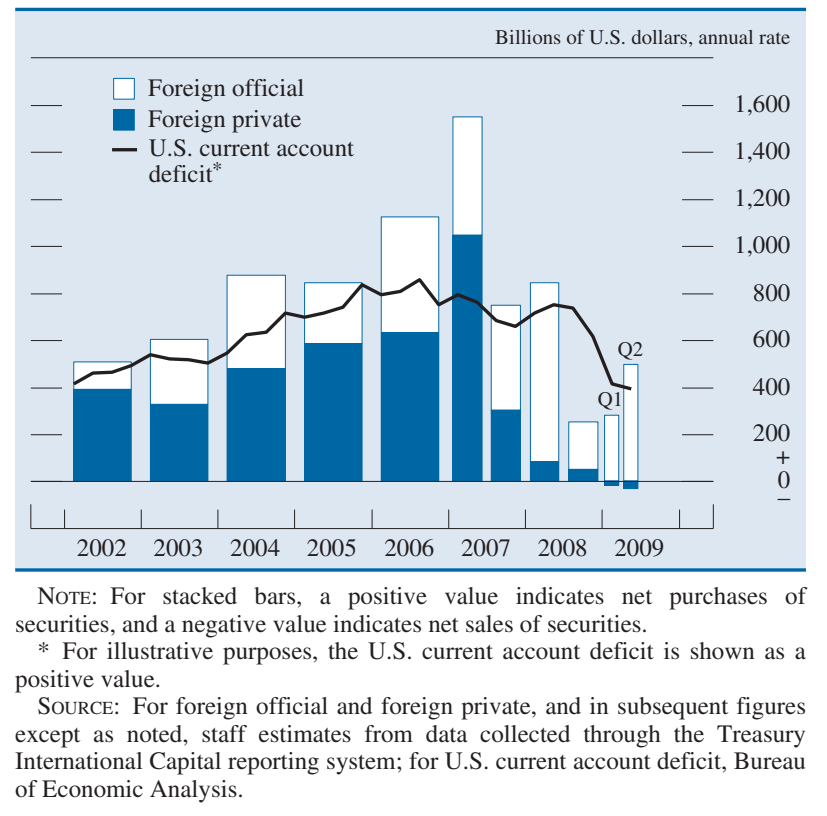

representing net purchases both by foreign private investors and by foreign official investors, typically amounted to more than the current account deficit (figure 1). Foreign private investors include foreign banks, non-government-operated investment funds, and foreign corporations, as well as individual investors. Foreign official investors are primarily foreign central banks and finance ministries but also include investment funds operated by central governments (so-called sovereign wealth funds). During the crisis, both types of investors exhibited flight to safety in their securities portfolios, with the result that total foreign purchases of U.S. securities fell below the current account deficit. This section discusses that flight to safety and the unusual flows resulting from the flight of U.S. investors out of foreign securities, which made up, in part, for the gap between the current account deficit and foreign purchases of U.S. securities.

\section{Increased Purchases of U.S. Treasury Securities}

As concerns rose over the risks associated with various U.S. securities that were structured around U.S. subprime loans and other forms of real estate loans and consumer credit during the summer of 2007, foreign investors began to acquire increasing amounts of U.S. Treasury securities, with corresponding movements out of other, riskier securities. We interpret these movements in cross-border portfolios 


\section{The Treasury International Capital Data Reporting System}

The primary data source for U.S. cross-border financial portfolio flows and positions is the data collected by the Treasury International Capital (TIC) reporting system. The TIC system includes monthly and quarterly data collected in aggregate by country, broad instrument type, and type of foreign counterparty, as well as periodic (now annual) in-depth surveys of cross-border holdings of both long- and short-term securities. ${ }^{1}$

\section{Components of the TIC System}

Information on foreign purchases of U.S. long-term securities and on U.S. purchases of foreign long-term securities is collected monthly on the TIC S form. Data are collected on foreign gross purchases and gross sales by country for four types of long-term U.S. securities: U.S. Treasury debt securities, U.S. agency debt securities, U.S. debt securities issued by all other institutions (primarily corporate issuers), and U.S. equity. These data distinguish foreign official purchases of U.S. securities from purchases by other foreigners. The TIC S form also reports U.S. cross-border purchases and sales of foreign longterm debt and equity, again by country. For analytical purposes, the sales of each type of security are usually subtracted from gross purchases to measure net transactions.

The TIC B forms collect data on cross-border positions in the form of deposits, loans, brokerage balances, and repurchase agreements. Although these data are commonly referred to as the TIC banking data, they also include positions reported by other depository institutions, by bank and financial holding companies, and by securities brokers and dealers. The TIC B forms also collect selected data on cross-border holdings of shortterm securities, such as short-term Treasury bills and certificates, commercial paper, and negotiable certificates of deposit. Like the TIC S data, the TIC B data are reported by country and by type of foreign counterparty.

Cross-border positions of nonbanks (including entities such as exporters and importers, industrial firms, insurance companies, and pension funds) are collected quarterly by country on the TIC C forms. These forms distinguish between "financial" claims and liabilities (such as deposits, short-term securities, and loans) and "commercial" claims and liabilities (such as accounts receivable or payable arising from import or export activities).

In addition to the monthly and quarterly data, morecomprehensive data on foreign holdings of U.S. securities and U.S. holdings of foreign securities are available from detailed annual surveys of cross-border portfolios. Because the annual survey data are collected at the indi-

1. For further information on the TIC system for collecting crossborder financial data, see Carol C. Bertaut, William L. Griever, and Ralph W. Tryon (2006), "Understanding U.S. Cross-Border Securities Data," Federal Reserve Bulletin, vol. 92 (May), pp. A59-A75, www.federalreserve.gov/pubs/bulletin/2006/cross_border_securities.pdf. vidual security level, the surveys can provide considerable additional information on cross-border securities holdings, including greater detail on the types of securities held, their maturity structure, and the face and market values of the individual securities.

\section{Financial Accounts of the Bureau of Economic Analysis and Adjustments to the TIC Data}

The TIC data, including both the monthly and quarterly data as well as the annual surveys, are the primary source data for many of the items in the official international financial transactions accounts compiled by the Bureau of Economic Analysis (BEA). In our analysis, we use estimates at a monthly frequency, prepared by staff members at the Federal Reserve Board, that are similar to those reported by the BEA. These flows may differ somewhat from the underlying as-reported TIC data, because the BEA and the Board's staff adjust reported flows to reconcile the information obtained from the monthly and quarterly data with that obtained in the annual surveys and other data sources. In particular, net purchases of securities attributed to foreign official investors are larger in this analysis than in the underlying TIC data because the TIC S data do not identify as foreign official acquisitions those that occur through foreign private intermediaries. Because of these additional acquisitions, when a new survey of foreign holdings of U.S. securities is conducted, foreign official holdings of U.S. securities are often revealed to be larger than would be estimated from summing official net purchases since the previous survey.

\section{Complications from the Financial Crisis in Assessing Correct TIC Reporting}

Aspects of the crisis itself have complicated the measurement of financial transactions and cross-border portfolio positions. In particular, bankruptcy filings and mergers and takeovers of major market participants generated changes in reporter panels as well as some unusual unwinding of positions that made it difficult to assess whether financial flows were being correctly reported. For example, Lehman Brothers Holdings Inc. held large cross-border positions in repurchase agreements, in which they lent securities to foreign banks in exchange for a cash loan. In order to correctly measure financial flows, it was necessary to determine the resolution of these and other such positions - that is, whether securities changed hands as a result of failure to repay, whether positions were taken over by companies acquiring subsets of Lehman's business, or whether the positions are still pending bankruptcy court outcomes.

In addition, changes in reporter classifications resulting from the creation of several bank holding companies generated new reporting responsibilities, which in turn generated inconsistent definitions of data series and further complicated the analysis of financial flows. 
2. Total foreign holdings and foreign official holdings of U.S. Treasury securities, 1995-2009

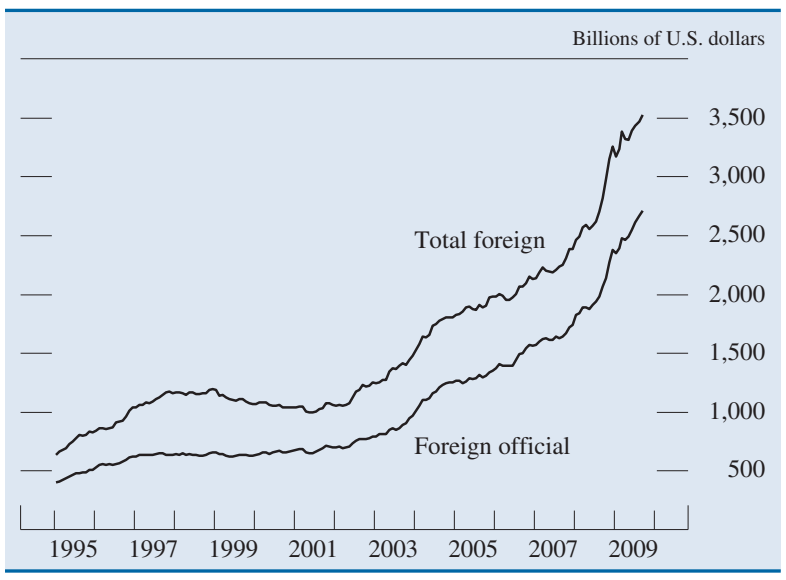

as reflecting changes in investor risk aversion or flight-to-safety portfolio motives. These movements became more pronounced with the intensification of the crisis in the fall of 2008 but reversed somewhat with the stabilization of financial markets through the first half of 2009.

Although foreign investors historically have held a large share of U.S. Treasury securities, most of these securities are held by official investors and, in large part, reflect official reserve holdings. Official holdings of U.S. Treasury securities grew especially rapidly between 2002 and mid-2007-more than doubling from roughly $\$ 700$ billion to more than $\$ 1.6$ trillion-as many Asian central banks acquired large amounts of dollar reserves over this period (figure 2). U.S. Treasury securities make up a much smaller share of foreign private portfolios and typically have accounted for a much smaller fraction of foreign private investors' purchases of U.S. securities: U.S. Treasury securities accounted for only about 12 percent of foreign private investors' securities holdings in 2003 and for less than 10 percent in 2006. Although foreign private investors made large purchases of Treasury securities during months of market turbulence (for example, in August 2007 and April 2008), they did not noticeably shift their purchases into such securities until the intensification of the crisis in the fall of 2008 (figure 3, solid bars). Foreign private monthly purchases reached a record $\$ 93$ billion in October 2008 and remained sizable through the first quarter of 2009.

Identifying the foreign counterparties for these recent large private purchases of Treasury securities is difficult. The TIC system that collects the underlying data for transactions in long-term securities is designed to record transactions between U.S. residents and their direct cross-border counterparties, not the ultimate investors. Thus, if an investor in France purchases a Treasury security but the transaction is booked through a London intermediary, the TIC system will report a sale of U.S. Treasury securities to the United Kingdom, not France. This example highlights the "financial center bias" in the data: Roughly one-third of all purchases and sales of U.S. long-term securities in the TIC system are recorded against the United Kingdom, with nearly as many recorded collectively against the Caribbean financial centers of the Bahamas, Bermuda, and the Cayman Islands.

Nonetheless, in both the summer of 2007 and the fall of 2008, net purchases of Treasury securities by entities in the Caribbean banking centers, especially the Cayman Islands, picked up notably. This increase in Treasury acquisitions is consistent with shifts in the portfolios of hedge funds and other investment funds located in these offshore financial centers to safer and more-liquid investments during periods of pronounced market turmoil. More recently, foreign private investors have reduced their purchases of Treasury securities, and net purchases of such securities through Caribbean financial centers have reversed to net sales. These developments may indicate increased risk tolerance and a diminution of "safe haven" flows.

Foreign official investors also increased their purchases of Treasury securities, especially in the second half of 2008, and their acquisitions of these securities have remained high in 2009 (figure 3, white bars). Total foreign acquisitions of Treasury securities (official and private purchases combined) amounted to more than $\$ 1$ trillion in the two years since summer 2007, raising estimated total foreign holdings to nearly $\$ 3.4$ trillion by mid-2009. However, because the issuance of Treasury securities has been heavy

3. Foreign net purchases of U.S. Treasury securities, by type of purchaser, 2002-09

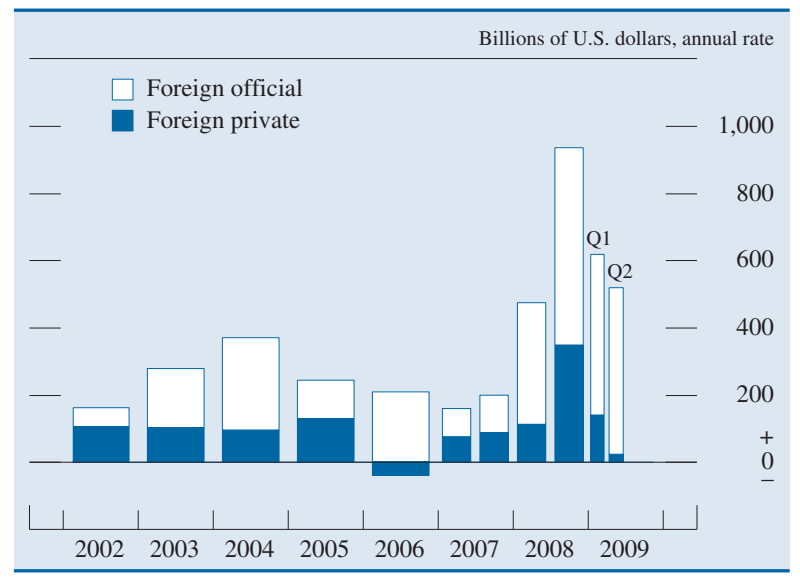

NotE: See general note to figure 1. 
4. U.S. Treasury securities outstanding, and foreign holdings of U.S. Treasury securities as a share of such securities outstanding, by type of security, 2006-09

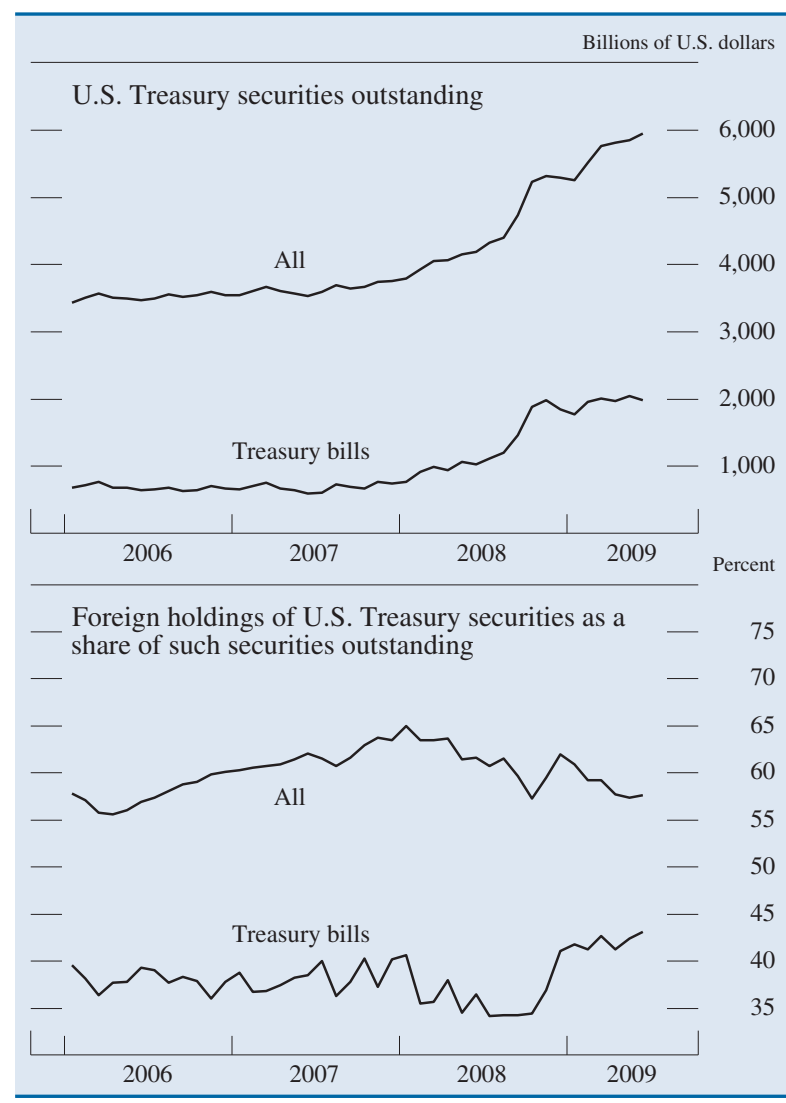

NotE: U.S. Treasury securities outstanding are constructed as marketable U.S. Treasury debt held by the public, excluding holdings of the Federal Reserve System Open Market Account.

SouRCE: For U.S. Treasury securities outstanding, staff estimates from U.S. Treasury, Monthly Statement of the Public Debt of the United States; and Federal Reserve Board, Statistical Release H.4.1, "Factors Affecting Reserve Balances." For foreign holdings of U.S. Treasury securities, staff estimates from data collected through the Treasury International Capital reporting system.

over the past two years, these record foreign acquisitions have not resulted in foreign investors acquiring a disproportionate share of U.S. Treasury securities outstanding. As of June 2009, foreign investors were estimated to hold about 58 percent of the marketable Treasury debt held by the public, a share about unchanged from June 2006 (figure 4). ${ }^{4}$

Foreign holdings of Treasury securities typically have been concentrated in long-term bonds and notes - that is, securities with an original maturity of more than one year. However, with the onset of the financial turmoil, a much larger fraction of both

4. We construct total marketable Treasury debt held by the public as the total marketable Treasury debt outstanding and held by the public as reported by the Monthly Statement of the Public Debt of the United States, minus Treasury securities held by the Federal Reserve System in the System Open Market Account. foreign official and foreign private acquisitions of Treasury securities has been Treasury bills: From June 2007 through June 2009, total foreign holdings of Treasury bills increased more than $\$ 625$ billion, to more than $\$ 850$ billion, accounting for about twothirds of the total increase in foreign holdings of Treasury securities. More than one-half of these short-term Treasury securities were acquired during the turbulent market conditions last fall. In part, increased foreign holdings of short-term Treasury securities reflect changes to the issuance patterns of Treasury debt last fall: Newly issued Treasury bills accounted for much more of the increase in debt outstanding than has been typical in recent years (figure 4, top panel). Nonetheless, the share of shortterm Treasury bills held by foreign investors has risen slightly over the past couple of years, from about 38 percent before the onset of the crisis to about 43 percent as of June 2009 (figure 4, bottom panel).

\section{Sharply Reduced Purchases of Other Types of U.S. Securities}

Although foreign private investors had made relatively small purchases of Treasury securities prior to the turmoil, they had made sizable acquisitions of other, riskier securities. Indeed, in 2005, 2006, and the first half of 2007, foreign private investors' acquisitions of long-term securities other than Treasury securities had accounted for the bulk of financial inflows. Their purchases, on net, of these other securities dropped to essentially zero in the first half of 2008 and reversed to sizable net sales in the second half of the year (figure 5). Foreign investors contin-

5. Foreign private net purchases of U.S. securities other than U.S. Treasury securities, by type of security, 2002-09

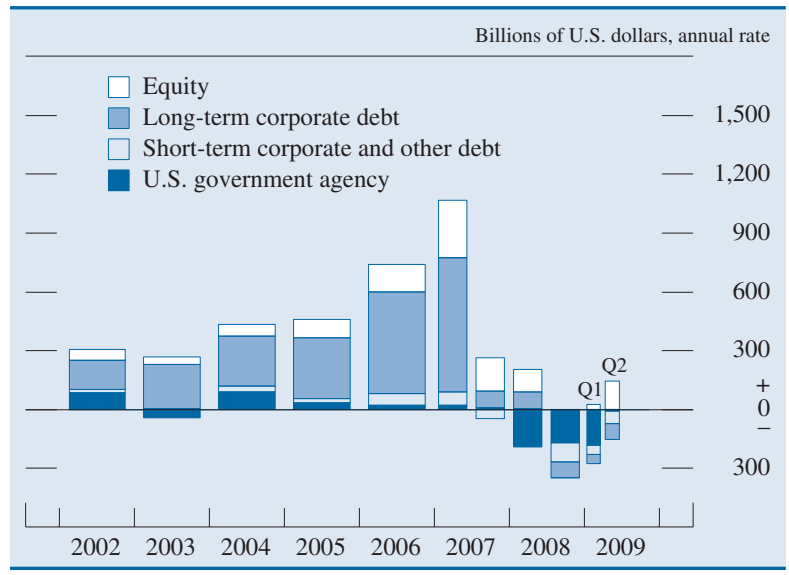

Note: Short-term corporate and other debt consists primarily of commercial paper, negotiable certificates of deposit, and bankers' acceptances. See also general note to figure 1 . 
ued to sell U.S. corporate and agency debt securities in early 2009 but resumed purchasing U.S. equity, especially in the second quarter.

Much of the falloff in foreign purchases of other types of securities reflects markedly reduced purchases of U.S. corporate debt securities: After amounting to more than $\$ 500$ billion of foreign inflows in 2006 and nearly $\$ 350$ billion in the first six months of 2007, foreign private net purchases of U.S. corporate debt totaled less than $\$ 50$ billion from summer 2007 through the end of 2008.

The reduction in U.S. corporate debt issuance since mid-2007 may have been a factor contributing to the marked slowdown in foreign net purchases of corporate debt securities over this period and especially in the fourth quarter of 2008. Foreign purchases of U.S. corporate debt partly reflect acquisitions of newly issued debt, and foreign gross purchases are correlated with U.S. corporate bond issuance (figure 6). Even as lower corporate issuance reduced foreign gross purchases of U.S. corporate debt, however, foreign sales of debt remained high because foreign gross sales of U.S. corporate debt partly reflect redemptions of maturing securities. According to the detailed survey data, roughly 8 percent of corporate debt held by foreign investors over the past two years had a remaining maturity of less than one year. With total foreign holdings of corporate debt amounting to $\$ 2.7$ trillion as of June 2007 and to $\$ 2.8$ trillion as of a year later, redemptions of maturing debt amount to about $\$ 225$ billion in each of those years and are thus recorded in the TIC system as sales of U.S. corporate debt by foreign residents. As new issuance of U.S. corporate debt slowed sharply, especially in the second half of 2008, net sales by foreign investors may have been explained, in part, by limited acquisitions of newly issued debt that were insufficient to offset the maturing bonds in their portfolios. But at the same time, net sales by foreign investors also indicated weak foreign demand for such securities, as limited issuance of U.S. corporate debt largely reflected weak demand by investors, including foreign investors.

Much of the previous foreign demand for longterm corporate debt appears to have been for corporate asset-backed securities (ABS), including sizable acquisitions of corporate mortgage-backed securities. Although the monthly transactions data over this period do not distinguish transactions in corporate ABS from transactions in other corporate debt securities, we can use information from the detailed surveys of foreign holdings of U.S. securities to learn more about the types of securities acquired. According to the survey data, foreign investors' holdings of corpo-
6. U.S. issuance, and foreign gross purchases, of U.S. corporate debt, 2006-09

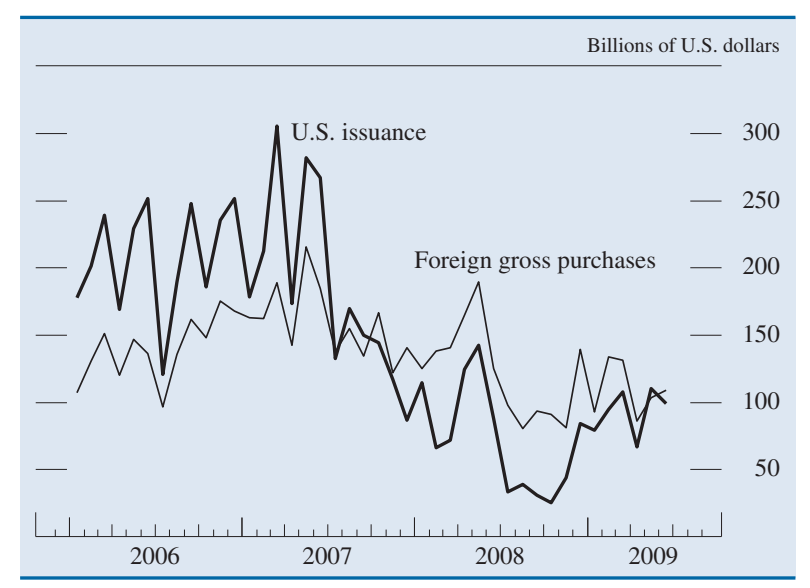

SouRCE: For U.S. issuance, staff estimates based on data from the Depository Trust \& Clearing Corporation and Thomson Financial; for foreign gross purchases, staff estimates from data collected through the Treasury International Capital reporting system.

rate ABS increased by more than $\$ 300$ billion between June 2006 and June 2007, accounting for more than 40 percent of the total increase in holdings of corporate debt securities. At $\$ 902$ billion, foreigners' holdings of corporate ABS accounted for about onethird of their holdings of corporate debt securities by the end of June 2007. ${ }^{5}$

By June 2008, however, foreign investors held only $\$ 760$ billion in U.S. corporate ABS, about $\$ 150$ billion less than they did the year before. In large part, the notably lower foreign holdings in June 2008 reflect sizable valuation losses on these securities: Compared with the relative stability in their prices over the previous 12 months, prices of corporate ABS fell roughly 13.5 percent by mid-2008 (see box "Difficulties in Assessing Market Values of Securities during the Financial Turmoil"). The underlying survey data indicate somewhat lower aggregate holdings of these securities as well. Nonetheless, foreign investors also appear to have continued buying some U.S. corporate ABS between the two surveys. Of the $\$ 760$ billion in corporate ABS held in June 2008, about $\$ 215$ billion reflects securities that were not held in 2007, including roughly $\$ 105$ billion in securities issued over the 12-month period. In contrast, roughly $\$ 280$ billion in individual corporate ABS held in 2007 was no longer held by June 2008.

Foreign investors did not substantially change their total holdings of short-term U.S. corporate debt

5. The underlying survey data indicate that most of the increase in the value of total foreign investment in U.S. corporate ABS between June 2006 and June 2007 appears to have arisen from increased foreign holdings rather than from valuation changes: The average effective price increase in these securities during that period was only about $1 \frac{1}{2}$ percent. 


\section{Difficulties in Assessing Market Values of Securities during the Financial Turmoil}

The Treasury International Capital surveys of foreign holdings of U.S. securities and U.S. holdings of foreign securities collect data both at face value (or, for equity, number of shares) and at market value as of the survey date (end of June for foreign holdings of U.S. securities and end of December for U.S. holdings of foreign securities). As part of the comprehensive process for reviewing the survey data, prices assigned to individual securities are crosschecked across survey respondents and with commercial data sources to verify the assigned market values. For securities such as Treasury securities or commonly traded U.S. equities, determining the correct price as of the survey dates is fairly straightforward: Because these securities trade in large, liquid markets, prices for the securities are readily available and easily verifiable.

If we want to understand how cross-border portfolios were affected by valuation gains or losses as the financial crisis unfolded, however, we need to be able to estimate such valuation changes for dates other than those of the surveys. This requirement is especially true for estimating valuation effects for foreign holdings of U.S. securities, because the most recent survey collected holdings in June 2008, before the intensification of the crisis in the fall of 2008. Estimating valuation gains or losses for periods beyond survey dates is a somewhat more complicated process because the composition of investor portfolios may change over the period. However, foreign holdings of most classes of U.S. securities such as U.S. Treasury securities and equities in aggregate are similar to the composition of standard price indexes of U.S. Treasury securities or of equities weighted by market capitalization. Thus, to create estimates of foreign holdings of U.S. securities for nonsurvey dates, we update the survey values of holdings with net purchases as recorded in the monthly transactions data, and we apply aggregate price indexes to these estimates to adjust for valuation gains or losses over nonsurvey intervals. Similarly, we can estimate valuation gains or losses on U.S. holdings of foreign equity and foreign debt by applying foreign equity and bond price indexes to our holdings of foreign securities. ${ }^{1}$

However, market conditions during the financial turmoil made the task of assessing market prices of securities that became very thinly traded extremely difficult, even on survey dates. This problem was especially true for corporate asset-backed securities (ABS), for which the difficulty was compounded by the very large number of securities involved. ABS typically are issued in different tranches. Each tranche is usually relatively small, and different risk characteristics may be associated with each tranche. As a result, many securities that superficially appear similar because they are issued by the same ABS issuer on the same date can have very different market

1. For more detail on how to construct monthly estimates of securities positions accounting for net transactions and valuation changes, see Carol C. Bertaut and Ralph W. Tryon (2007), "Monthly Estimates of U.S. Cross-Border Securities Positions," International Finance Discussion Papers 910 (Washington: Board of Governors of the Federal Reserve System, November), www.federalreserve.gov/pubs/ifdp/2007/910/ ifdp910.pdf. values because of their different risk characteristics, a fact that makes crosschecking and verifying prices across reporters and with commercial data sources considerably more difficult. Furthermore, prices were more difficult to obtain for some ABS - particularly those in smaller, more risky tranches-than for others. As market functioning for ABS became impaired, tracking prices became harder, especially for these more risky tranches. And although riskier tranches tend to be smaller, they are numerous and in aggregate can account for a sizable portion of crossborder positions. For example, the June 2008 survey of foreign holdings of U.S. securities identified roughly 8,000 individual ABS with face values of more than $\$ 25$ million. These 8,000 securities accounted for roughly three-fourths of the total face value of corporate ABS held by foreigners. But more than 28,000 individual ABS, each with a face value of $\$ 25$ million or less, collectively accounted for the remaining one-fourth of corporate ABS held. A further complication has been that many ABSparticularly those issued in the Cayman Islands and held by U.S. investors-were privately placed, with little information on the price of the securities even at issue, let alone on the price as of the survey date.

ABS price indexes can provide some guidance on how ABS prices are likely to have moved between surveys, besides providing a means to estimate more recent valuation gains or losses. Because roughly two-thirds of U.S. corporate $\mathrm{ABS}$ held by foreign investors was floating-rate debt, using an average of an index of floating-rate ABS, such as the Barclays Capital U.S. Floating-Rate AssetBacked Securities Index, and an index of fixed-rate ABS, such as the Barclays Capital U.S. Asset-Backed Securities Index, is a reasonable guide to estimating current valuation effects. By this measure, prices for U.S. corporate ABS were little changed between June 2006 and June 2007 but fell roughly 13 percent between July 2007 and June 2008; they had declined a further 18 percent by year-end 2008 (figure A). Although these price declines are sizable, they may actually understate total foreign losses on U.S. corporate $\mathrm{ABS}$, as the indexes themselves capture price changes only for securities that are actively traded.

A. Change in prices of U.S. corporate asset-backed securities, by type of security, 2006-09

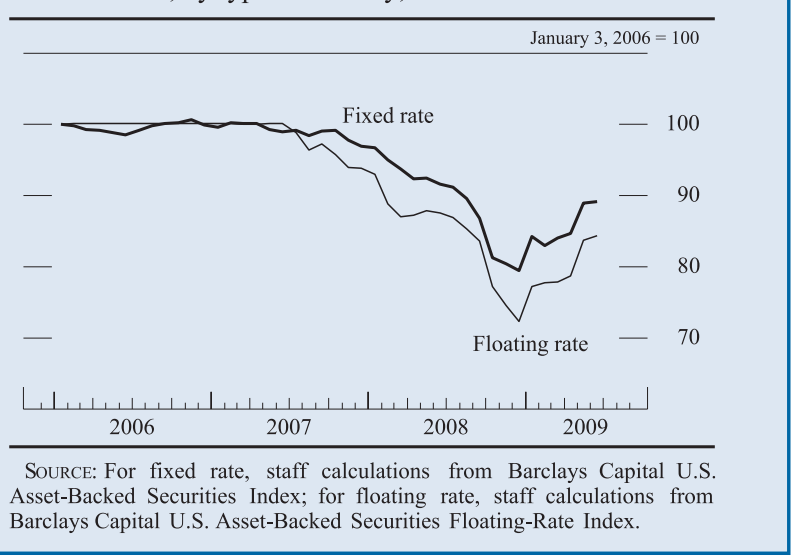


between June 2007 and June 2008. However, as with long-term debt, the asset-backed portion of foreign holdings declined. In mid-2007, asset-backed commercial paper (ABCP) accounted for nearly 40 percent of foreign holdings of U.S. short-term corporate debt. By mid-2008, this figure had declined to about 25 percent. Starting in the third quarter of 2008 , as short-term funding markets ceased normal functioning, foreign investors did decrease their overall positions in short-term U.S. corporate debt. Such positions dropped about 30 percent between June and December of 2008 and continued falling more gradually in 2009, losing another 10 percent by June 2009 .

Foreign private investors also slowed their net purchases of U.S. government agency debt and equity in the second half of 2007, turning to net sales of these securities in 2008. However, the magnitude of this reversal was considerably less dramatic than the marked slowdown in net purchases of corporate debt securities. Although concerns about the financial viability of Fannie Mae and Freddie Mac gained particular market attention in the summer of 2008, foreign private investors had been net sellers of agency securities since mid-2007. Foreign private interest in agency debt does not appear to have been affected by the move in September 2008 to place Fannie Mae and Freddie Mac into conservatorship, as foreign private net sales of agency securities have continued thus far in 2009, though at a somewhat slower pace than in the previous few quarters.

Although foreign private purchases of U.S. equity did show some sizable swings during months of more pronounced market turmoil, foreign acquisitions, on net, were not affected to the same degree as were foreign purchases of corporate debt securities. Foreign purchases of equity remained sizable in the second half of 2007. And despite the sharp drop in U.S. equity prices in the fall of 2008 , foreign investors made only limited net sales of U.S. stocks, though, as we discuss in the section "Marked Slowdown in Cross-Border Securities Trading" (p. A162), gross trading in U.S. equity was sharply curtailed. More recently, foreign investors have returned to purchasing U.S. equity.

\section{Portfolio Shifts for Foreign Official Investors}

Foreign official investment has typically occurred through purchases of U.S. Treasury securities, but in recent years, official investors began to acquire an increasing amount of U.S. agency securities (figure 7). For the period 2005 through summer 2007, official purchases of agency securities accounted for about one-half of all official inflows. During this
7. Foreign official net purchases of U.S. securities, by type of security, 2002-09

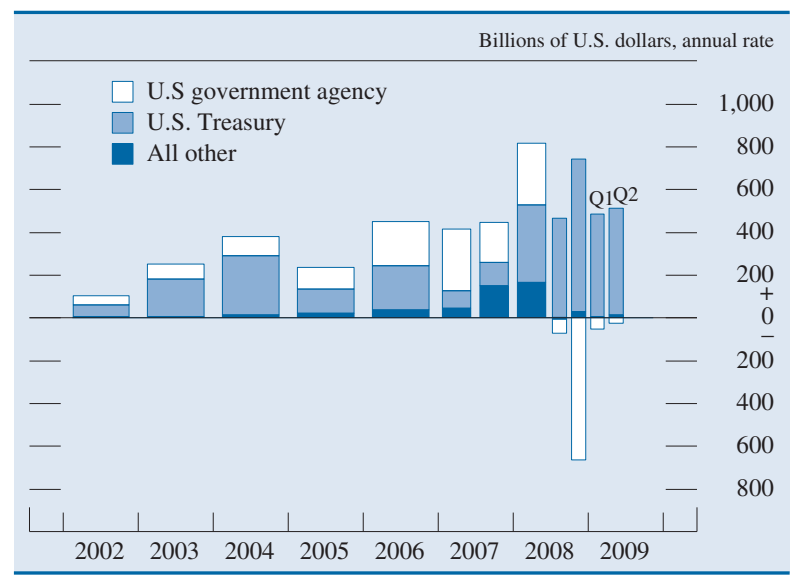

Note: All other consists of long-term corporate debt and equity. See also general note to figure 1 .

period, foreign official purchases of agency securities accounted for more than two-thirds of the net issuance of agency debt.

The composition of foreign official inflows was little affected by the onset of financial turmoil in mid-2007 but changed markedly with the intensification of the turmoil in the second half of 2008. As we saw with foreign private investors, official investors made large net purchases of Treasury securities and net sales of other types of securities beginning in summer 2008. However, some special factors influenced the timing and extent of the shift in the composition of official inflows.

Official net purchases of agency securities remained strong in 2007 and through the first half of 2008 but began to weaken as concerns about Fannie Mae and Freddie Mac began to surface in July 2008. Beginning in July 2008, most official investors appeared to allow maturing issues of long-term agency securities in their portfolios to be redeemed without making offsetting new purchases, resulting in a small net decline in their holdings of agency securities. From October 2008 through the end of that year, however, some official investors made sizable outright sales of their holdings of agency securities as they intervened to support their currencies. These outright sales of agency securities continued through the end of 2008 and contributed to an unusual net outflow from official investors for the quarter.

Official investors had also acquired increasing amounts of other U.S. securities, primarily U.S. corporate stocks and bonds, in 2006 and the first half of 2007. These official inflows largely reflect acquisitions by sovereign wealth funds willing to invest in somewhat riskier U.S. securities. Although inflows 
into such securities actually picked up in the second half of 2007 and the first half of 2008, they, too, reflect aspects of the financial turmoil: Official purchases in late 2007 and early 2008 were boosted by the well-publicized injections of capital by some sovereign wealth funds into U.S. financial institutions as the financial crisis unfolded.

So far in 2009, official inflows have remained sizable, but they continue to be concentrated in U.S. Treasury securities.

\section{Flight-to-Safety Shifts in Securities Portfolios of U.S. Investors}

U.S. purchases of foreign securities are outflows in the financial account and thus typically offset some of the financial inflows recorded through foreign official and foreign private purchases of U.S. securities. U.S. investors had acquired increasing amounts of foreign stocks and bonds from 2004 through the first half of 2007. They continued to acquire foreign securities through the first half of 2008, though at a reduced pace, but began to sell foreign securities in the summer of 2008 (figure 8). These record sales of foreign securities in the second half of 2008 provided a financial inflow to the United States, making up, in part, for the gap between the current account deficit and foreign purchases of U.S. securities evident in figure 1 .

Increased risk aversion and an interest in reducing foreign exposure (a form of flight to safety) are likely motivations for the pullback in U.S. investors' holdings of foreign securities, especially investments in foreign equity, which are the bulk of U.S. external securities portfolios. U.S. investors continued to acquire foreign equity through the first half of 2008

8. U.S. net purchases of foreign securities, by type of security, 2002-09

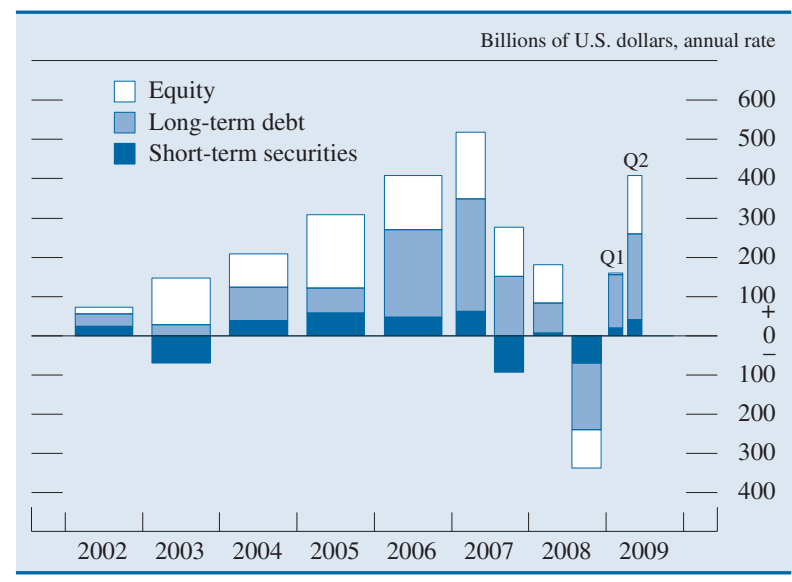

NoTE: See general note to figure 1 . but made fairly sizable net sales of foreign equity in the second half of 2008 as foreign stock markets plunged.

U.S. residents' net purchases of foreign bonds slowed notably in the first half of 2008 and reversed to large net sales in the second half of that year. As with foreign purchases of U.S. corporate bonds, the deterioration in U.S. purchases of foreign bonds may reflect, in part, weak global debt issuance since the onset of the turmoil. Another similarity to the foreign sales of U.S. corporate debt is an apparent reduction in U.S. demand for foreign-issued ABS. Although the majority of foreign debt securities owned by U.S. investors are conventional debt securities issued by foreign governments and corporations, a sizable portion of the increase in U.S. investors' holdings of foreign long-term debt between 2005 and the onset of the crisis came from increased purchases of foreignissued ABS. ${ }^{6}$ Of the $\$ 720$ billion in foreign privatesector debt held by U.S. residents at year-end 2005, about $\$ 131$ billion, or roughly 18 percent, consisted of foreign-issued ABS. By the end of 2007, total holdings of foreign private-sector debt had grown to $\$ 1.2$ trillion, and holdings of foreign ABS had more than doubled, increasing to $\$ 330$ billion, which accounted for 27 percent of foreign private-sector debt held.

By December 2008, U.S. investors' holdings of foreign private-sector debt had declined to $\$ 945$ billion, and holdings of foreign ABS had decreased to $\$ 231$ billion. As with foreign holdings of U.S.-issued corporate $\mathrm{ABS}$, much of the decline in the market value of holdings of foreign ABS between 2007 and 2008 reflects sizable estimated valuation losses on this debt: Between December 2007 and December 2008 , prices of these securities are estimated to have fallen roughly 25 percent.

U.S. residents' holdings of foreign-issued shortterm debt also grew rapidly in the years before the crisis, reaching $\$ 368$ billion by December 2006 . Much of this increase likely reflected increased holdings of foreign $\mathrm{ABCP}$ : The share of commercial paper (ABCP and unsecured) in these holdings increased from about 15 percent in December 2003 to almost 50 percent in December 2006. This fraction stayed

6. Much of this foreign-issued ABS was backed, at least in part, by U.S. loans; this characteristic of foreign-issued ABS was especially true for U.S. holdings of ABS issued through the Cayman Islands, which amounted to nearly $\$ 200$ billion in December 2007. For further information, see Daniel O. Beltran, Laurie Pounder, and Charles Thomas (2008), "Foreign Exposure to Asset-Backed Securities of U.S. Origin," International Finance Discussion Papers 939 (Washington: Board of Governors of the Federal Reserve System, August), www.federalreserve.gov/pubs/ifdp/2008/939/ifdp939.pdf. 
fairly constant at about 50 percent over 2007 and 2008, while total holdings of short-term foreign debt dropped. Overall, from the onset of the crisis in August 2007 through March 2009, U.S. holdings of short-term foreign debt declined by about one-third.

With an easing of tensions in financial markets, an improved environment for foreign bond issuance, and a recovery in global equity markets so far this year, U.S. residents have resumed purchases of both foreign stocks and bonds.

\section{BANKING DEVELOPMENTS}

Banks' cross-border positions (which include some positions of securities brokers) are quite volatile, and large net flows for a given month are not unusual. Over longer periods of time, however, banking usually contributes little to net U.S. financial flows, as was the case for the period 2004 through early 2007 (figure 9, solid bars). However, since mid-2007, cross-border banking flows have exhibited unusual patterns that reflect features of the financial crisis.

Even as the crisis slowed the growth in gross positions, net changes in positions showed a substantial increase in net lending abroad, or outflows, between mid-2007 and mid-2008. These outflows were followed by a large inflow between September and December 2008 as previous net lending was retracted; finally, renewed sizable outflows from January to June 2009 reflected a resurgence in net lending. Over the whole period from August 2007 to

9. U.S. cross-border net banking flows for banks' own accounts, and central bank swap flows and other U.S. official asset flows, 2004-09

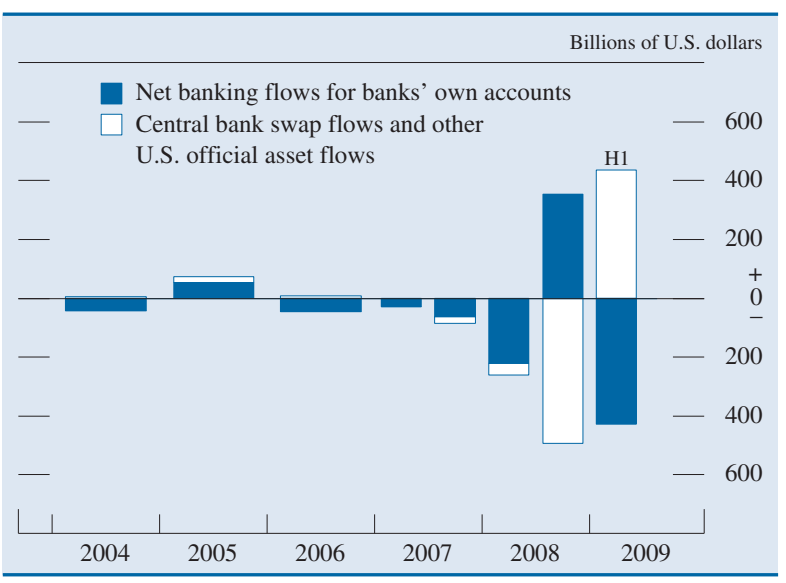

Note: Semiannual values not annualized. A positive value indicates a net financial inflow to the United States, and a negative value indicates a net financial outflow from the United States.

SOURCE: For net banking flows for banks' own accounts, staff estimates from data collected through the Treasury International Capital reporting system; for central bank swap flows and other U.S. official asset flows, Federal Reserve Board, Statistical Release H.4.1, "Factors Affecting Reserve Balances."
10. Banking offices in the United States: Banks' own gross cross-border claims on foreigners, and their own gross cross-border liabilities to private foreigners, 2004-09

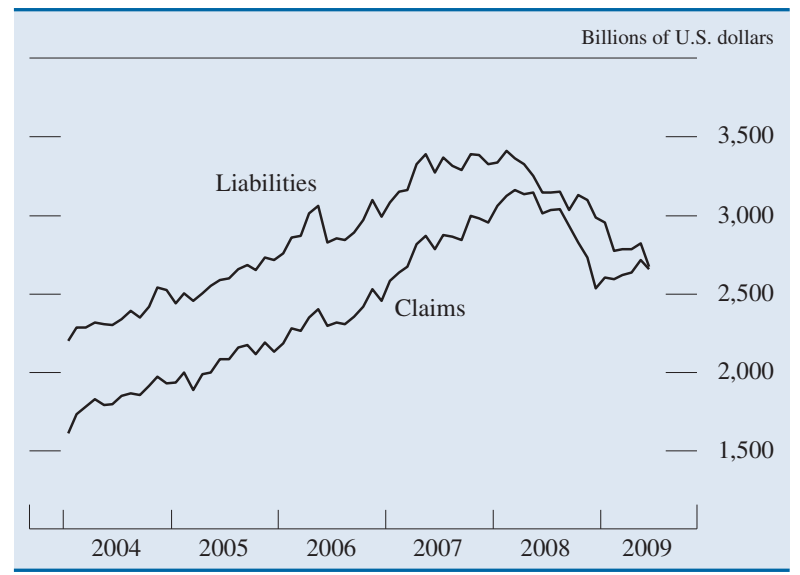

June 2009, new net lending abroad by banks in the United States cumulated to about $\$ 480$ billion.

This pattern was driven mainly by significant U.S. dollar liquidity needs of European banks. Through much of the crisis, banks located in the United States played a primary role in funding dollar needs abroad. During the height of the crisis in the fall of 2008, however, foreign central banks provided dollars, drawn from their swap lines with the Federal Reserve, to foreign banks directly. This section will elaborate on these unusual flows from banking and the official swap lines (figure 9, white bars).

\section{Background on Cross-Border Banking Positions}

Gross cross-border positions reported by banks in the United States are sizable: Gross cross-border claims and liabilities each represent just more than one-fifth, respectively, of U.S.-owned assets abroad (claims) and foreign-owned assets in the United States (liabilities) in the U.S. international investment position. At the end of 2007, these positions amounted to about $\$ 3.8$ trillion in gross claims on foreigners and about $\$ 4.2$ trillion in gross liabilities to private foreigners. Most of these positions, about 80 percent on each side, are banks' own claims and liabilities. We report banks' own gross positions in recent years (figure 10). The remaining 20 percent of the positions are banks' holdings of short-term securities and deposits on behalf of customers, which are discussed elsewhere in this article. ${ }^{7}$

7. Changes in customers' short-term securities portfolios are discussed earlier in the section "Flight-to-Safety Shifts in Portfolios during the Crisis" (p. A148). The decline in customers' banking 
11. Banking offices in the United States: Gross crossborder claims on foreigners and gross cross-border liabilities to private foreigners, by nationality of parent bank, 2004-08

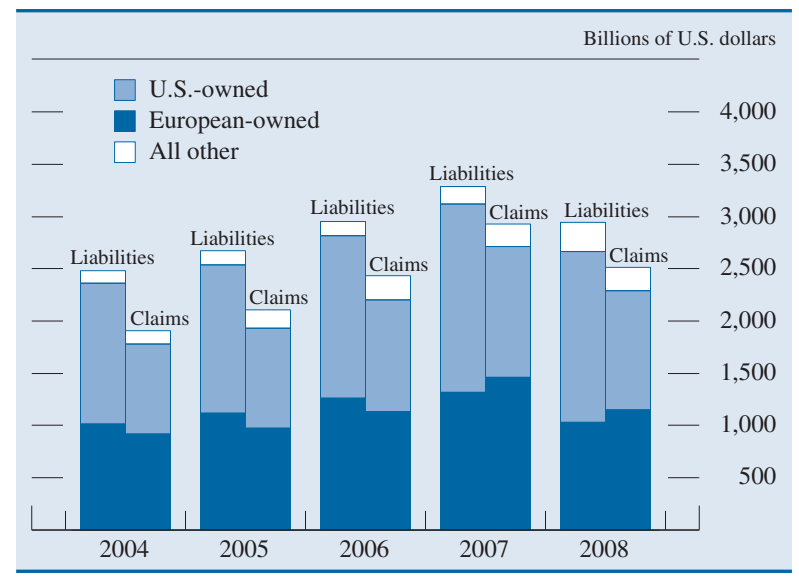

Banks' own cross-border claims consist mainly of deposits with foreign banks, loans, resale agreements, and their holdings of foreign certificates of deposit (CDs) and short-term securities. Banks' own crossborder liabilities consist mainly of deposits by foreigners and repurchase agreements (repos). A substantial fraction-more than two-thirds - of banks' own cross-border positions are with affiliated banking offices abroad (that is, intercompany positions).

By definition, banking offices located in the United States include both U.S.-owned banks and U.S. offices of foreign-owned banks. Therefore, for foreignowned banks in the United States, affiliated offices abroad include the parent office. Gross U.S. crossborder positions are roughly split between U.S.owned banks and offices of banks headquartered in Europe (figure 11). Banking offices with headquarters elsewhere (primarily Asia, Canada, and Australia) account for less than 10 percent of gross positions.

For several years before the crisis, U.S.-owned banks, as a group, were substantial net borrowers from abroad, which means that their liabilities exceeded their claims (figure 12, top panel, shaded area). However, this position was fairly stable, with little new net borrowing or lending over the 2004 to 2006 period. Offices of foreign-based banks, which are primarily European, maintained a more neutral cross-border position in the pre-crisis period: Claims were nearly equal to liabilities (figure 12, bottom panel). These positions also created little new net borrowing or lending before 2007.

positions is discussed in a later section, "Reductions in Foreign Exposure in Securities, Banking, and Nonbank Positions" (p. A160).
12. Banking offices in the United States: Gross crossborder claims on foreigners, gross cross-border liabilities to private foreigners, and net position for U.S.-owned offices and for European-owned offices, 2004-09

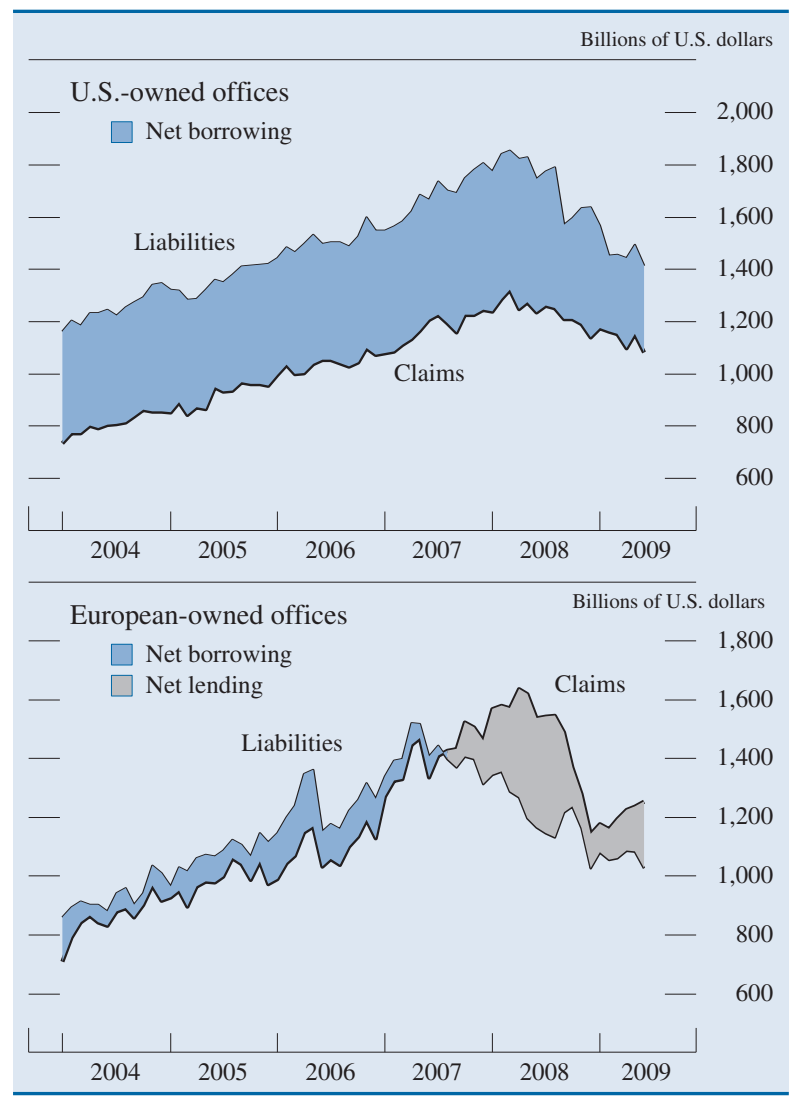

\section{Increased Net Lending through Mid-2008}

Normally, banks generate little net flows, meaning little new net borrowing or lending, because banks' gross cross-border liabilities to foreigners and gross cross-border claims on foreigners typically grow at about the same rate. However, between mid-2007 and mid-2008, a substantial gap opened between the paths of liabilities and claims (figure 13, top panel). New net lending, by our definition, occurs when claims rise relative to liabilities, regardless of the absolute position of claims and liabilities initially. Figure 13 illustrates new net lending by showing the cumulative changes in claims and liabilities. At its peak in early fall of 2008 , this gap cumulated to about $\$ 430$ billion in new net lending abroad by banks located in the United States since January 2007, about $\$ 390$ billion of which occurred between August 2007 and August 2008. The gap then narrowed dramatically through the fall of 2008, retracting nearly 80 percent of that lending, but opened again beginning in January 2009, 
13. Banking offices in the United States: Cumulative changes since 2004 in gross cross-border claims on foreigners and in gross cross-border liabilities to private foreigners, and new net borrowing or lending, for all offices and for European-owned offices, 2004-09

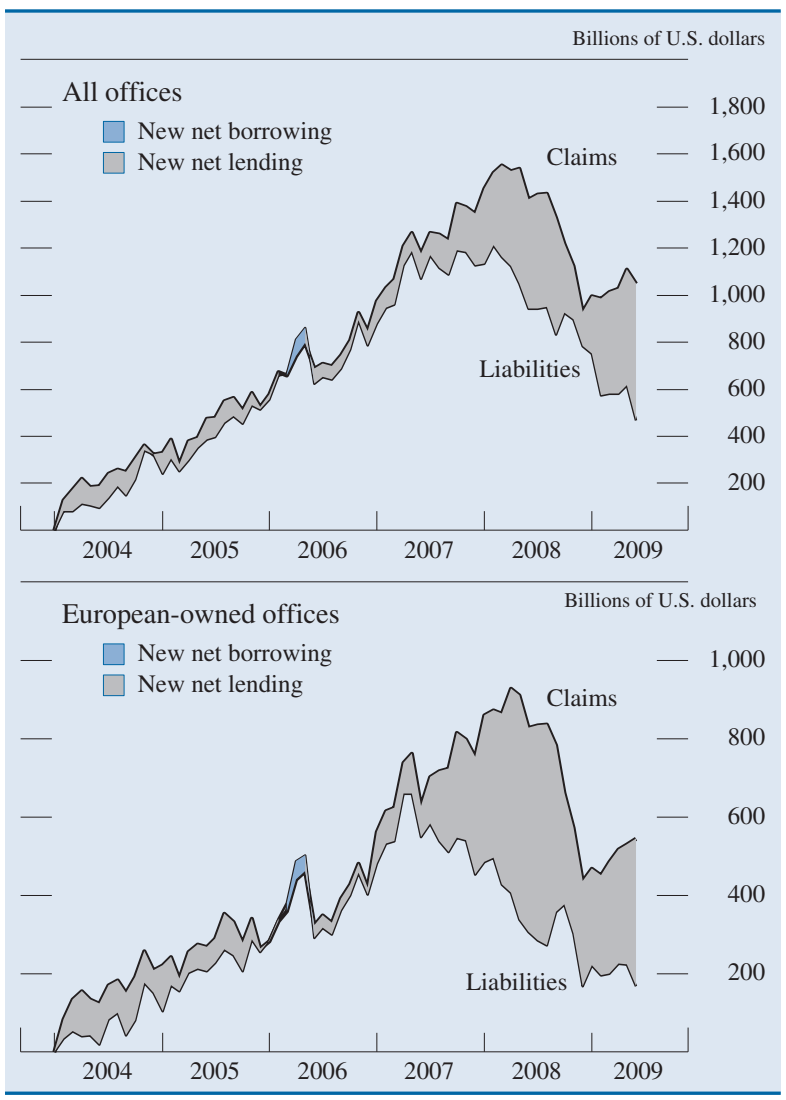

cumulating to about $\$ 435$ billion in new net lending between January and June 2009.

\section{European-Owned Banks}

The increased net lending abroad between mid-2007 and mid-2008 is mainly attributable to U.S. offices of European-owned banks lending to their affiliated offices in Europe. Although U.S. banking offices with European parents make up less than one-half of U.S. gross cross-border positions, their increased lending more than explains the overall pattern for the first year of the crisis (figure 13, bottom panel). Europeanowned offices in the United States generated an outflow of more than $\$ 450$ billion over the first year of the crisis (figure 14). Furthermore, almost all of that new lending was to affiliated offices, often the parent office.

In the several years prior to the crisis, many European banks directly or indirectly sponsored more than 100 special purpose vehicles (SPVs), including
14. Net flows of U.S.-owned and European-owned banks and of banks with owners of other nationalities, August 2007 through August 2008

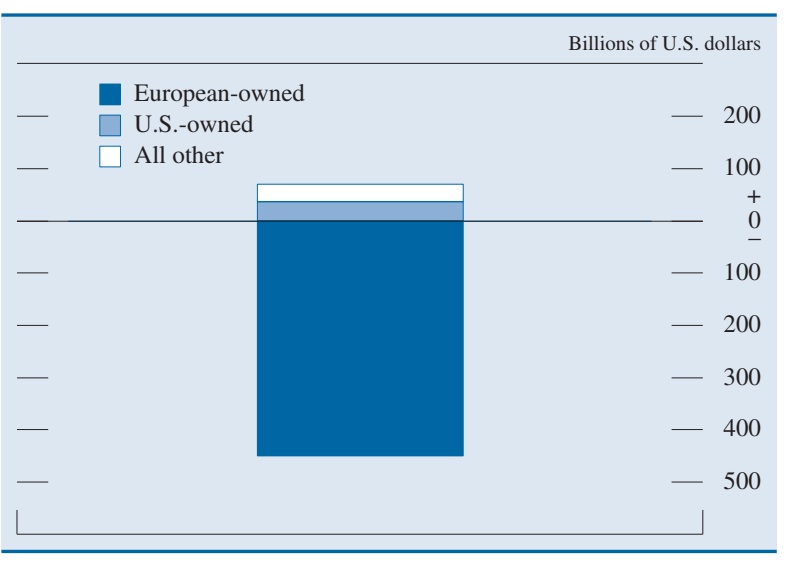

Note: A positive value indicates a net financial inflow to the United States, and a negative value indicates a net financial outflow from the United States.

structured investment vehicles (SIVs). These vehicles issued hundreds of billions of dollars of ABS, including $\mathrm{ABCP}$, into the U.S. market. When ABCP markets froze in the fall of 2007, European banks not only lost a source of new funding, but also needed to pay off the commercial paper and medium-term notes maturing throughout late 2007 and early 2008 that could not be rolled over in the market. ${ }^{8}$ Because many of the assets backing the commercial paper were illiquid, European banks needed other sources of U.S. dollars. This need added substantially to the demand for dollars by European banks at a time when liquidity was at a premium and financial markets, including foreign exchange markets, were under stress from many angles.

The notion of a dollar liquidity crunch in Europe is supported by the fact that net lending to Europe during the first year of the crisis was widespread across many banks, whereas banking flows are usually dominated by the few largest banks. The U.S. offices of 30 banks each lent more than $\$ 10$ billion abroad, on net, between August 2007 and August 2008. ${ }^{9}$ Of those banks, 22 were European owned, and all but 4 had sponsored SPVs.

\section{U.S.-Owned Banks}

If Europe had such strong demand for dollars, why were U.S.-owned banks not also lending to Europe?

8. Although the ABS were liabilities of the SPVs and not of the banks themselves, most banks chose, as a matter of reputation, to intervene to support the SPVs they had created.

9. In this analysis, securities brokerage arms that report separately (for example, J.P. Morgan Worldwide Securities Services) are counted as separate banks. 
15. Summed net flows and gross positions of U.S.-owned banks, August 2007 through August 2008

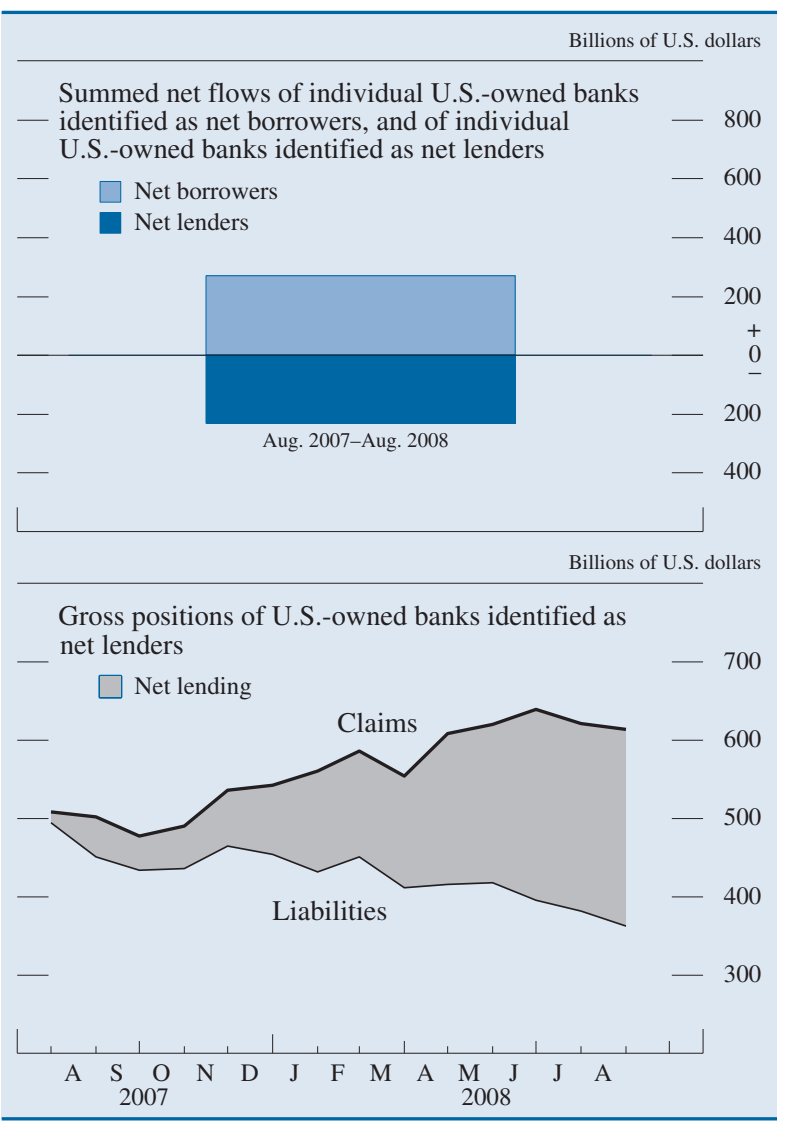

Note: For summed net flows, a positive value indicates a net financial inflow to the United States, and a negative value indicates a net financial outflow from the United States. The outflows from net lenders shown in the top panel reflect the change in gross positions shown in the bottom panel.

The net position of U.S.-owned banks changed little during the first year of the crisis, generating a small net inflow. But this result obscures the many ways that cross-border flows of U.S.-owned banks responded to the crisis. Some U.S.-owned banks actually did lend abroad - as much as $\$ 235$ billion during the first year of the crisis (figure 15, top panel). However, those amounts were more than offset by about $\$ 270$ billion in inflows from other U.S.-owned institutions that were net borrowers. This latter group of U.S.-owned banks appears to have borrowed from foreign affiliates to shore up the liquidity of the parent bank, similar to the behavior of the European-owned banks. Presumably their need for liquidity at home outweighed the profit to be gained from lending abroad. A majority of the $\$ 270$ billion in inflows generated by these U.S.-owned net borrowers was attributable to securities brokers. These institutions did not have access to borrowing from the Federal Reserve early in the crisis and likely turned to their own foreign offices instead for needed cash.

The group of U.S.-owned banks that generated $\$ 235$ billion in outflows, or net lending, during the first year of the crisis had both increasing gross cross-border claims and decreasing gross cross-border liabilities (figure 15, bottom panel). Looking at each bank individually suggests that this group encompasses two very different sets of banks in terms of their situation and behavior during the crisis. One set had increasing gross claims abroad over the first year of the crisis and roughly flat gross liabilities. In particular, these banks increased their gross claims on unaffiliated foreigners during this period, suggesting that they were lending to European banks and not just their own offices abroad. Such banks presumably had sufficient liquidity at home to enable them to fulfill some of the dollar demand in Europe.

In contrast, a second set of U.S.-owned banks and brokers started from a large net borrowing position (meaning that their liabilities to foreigners were greater than their claims on foreigners) and then saw their gross cross-border liabilities plummet nearly 50 percent during the first year of the crisis, which also generated outflows. If these institutions were among those in which the market lost confidence, such that foreign counterparties were unwilling to continue lending to them, then these U.S.-owned banks and brokers would have been forced to pay off their liabilities to foreigners. This situation is a plausible explanation for the data pattern. Indeed, this set includes some institutions that eventually required substantial government rescues or entered bankruptcy. When only net flows are considered, the data for these two very different sets of U.S.-owned banks are observationally equivalent. Although only one set of banks actually lent more abroad, both sets produced net outflows, which are generally referred to as net lending.

During the first year of the crisis, many of the depository institutions that lent abroad (or generated outflows), both U.S.-owned and European-owned offices, also borrowed from the Federal Reserve's discount window, which included use of the Term Auction Facility. But even among those banks, average borrowings from the discount window during that period equaled at most 10 percent of their net lending abroad, suggesting that the Federal Reserve was not the primary source of those funds. 


\section{Crisis Intensification: September to December, 2008}

Starting in September 2008, however, the Federal Reserve began to play a key role in providing dollar liquidity abroad. In response to the severe dollar shortage, the Federal Reserve dramatically increased the availability of dollars to foreign central banks through liquidity swap facilities. Outstanding amounts drawn on the swap lines reached $\$ 288$ billion in September, $\$ 534$ billion in October, and a peak of $\$ 554$ billion at the end of December 2008. More than three-fourths of these funds were drawn by central banks in Europe.

Because of the swap lines, the foreign banks that had been borrowing heavily from their U.S. offices were able to obtain dollars directly from their own central banks. In response, the U.S. offices of many of those foreign banks were able to decrease their lending position to their parents, receiving a flow of funds back into the United States between September and December of 2008. Specifically, European-owned banks accounted for inflows of about $\$ 290$ billion over this period (figure 16).

The cross-border flows of U.S.-owned banks also showed the severity of the crisis during this period. U.S.-owned banks that had been lending early in the crisis stopped lending. Meanwhile, nearly all securities brokers, even those that had been able to borrow from affiliates earlier in the crisis, generated large outflows as their borrowings from foreigners collapsed. These events resulted largely from the breakdown in the market for repos, an important source of funding for many securities brokers. Finally, U.S.owned depository institutions that had been borrowing from their foreign offices abroad also decreased

16. Net flows of U.S.-owned and European-owned banks and of banks with owners of other nationalities, September 2008 through June 2009

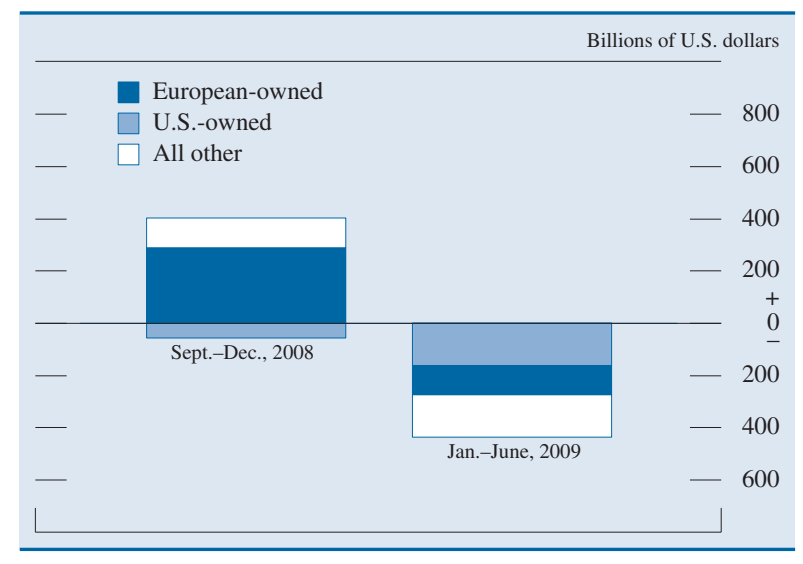

NotE: See note to figure 14. that borrowing, possibly because more funds were available at home from the Federal Reserve at the height of the crisis.

\section{Gradual Improvement in 2009}

As the tone of interbank markets began to improve slowly during the winter, foreign central banks decreased their drawings on the swap lines with the Federal Reserve, leaving $\$ 310$ billion outstanding at the end of March and just $\$ 114$ billion at the end of June. The decline in the swaps is recorded as an inflow for the United States as the Federal Reserve decreases its claims on foreign central banks. Private banking offices in the United States (this time, more U.S. and Asian banks than European banks) stepped back in to provide dollar liquidity abroad (figure 16). Between January and June of 2009, net bank lending abroad increased almost dollar for dollar with the decline in the swaps, an indication that the strength of demand for dollar funding abroad was undiminished but that banks regained the ability to provide that funding through interbank markets in the first half of 2009.

Overall, cross-border bank flows reflected the crisis through the channeling of liquidity "home" to protect the parent bank, with European banks generating by far the strongest net flows from U.S. offices in order to meet extraordinary demand for dollars in Europe. This channeling of liquidity and the subsequent breakdown in interbank markets, failure of banking institutions, and intervention of central banks reflected concerns over risk similar to those we saw in the cross-border securities flows. These characteristics of the crisis are also apparent in the contraction of gross banking positions, discussed in the next section.

\section{REDUCTIONS IN FOREIGN EXPOSURE IN SECURITIES, BANKING, AND NONBANK POSITIONS}

As discussed earlier, increased risk aversion during the crisis led to notable flight-to-safety flows in securities portfolios, including net sales of foreign assets by U.S. investors and net sales of riskier U.S. assets by foreign investors, as well as flows due to banks channeling liquidity "home." Flows, of course, represent changes in positions, so these movements imply a broad reduction in outstanding cross-border positions-in other words, a retraction of foreign exposure. Perhaps surprisingly, however, such reductions are significant only in banking and certain other nonsecurities positions. 
17. Foreign holdings of U.S. securities adjusted for foreign net acquisitions, and such holdings also adjusted for valuation changes, by type of security, 2005-09

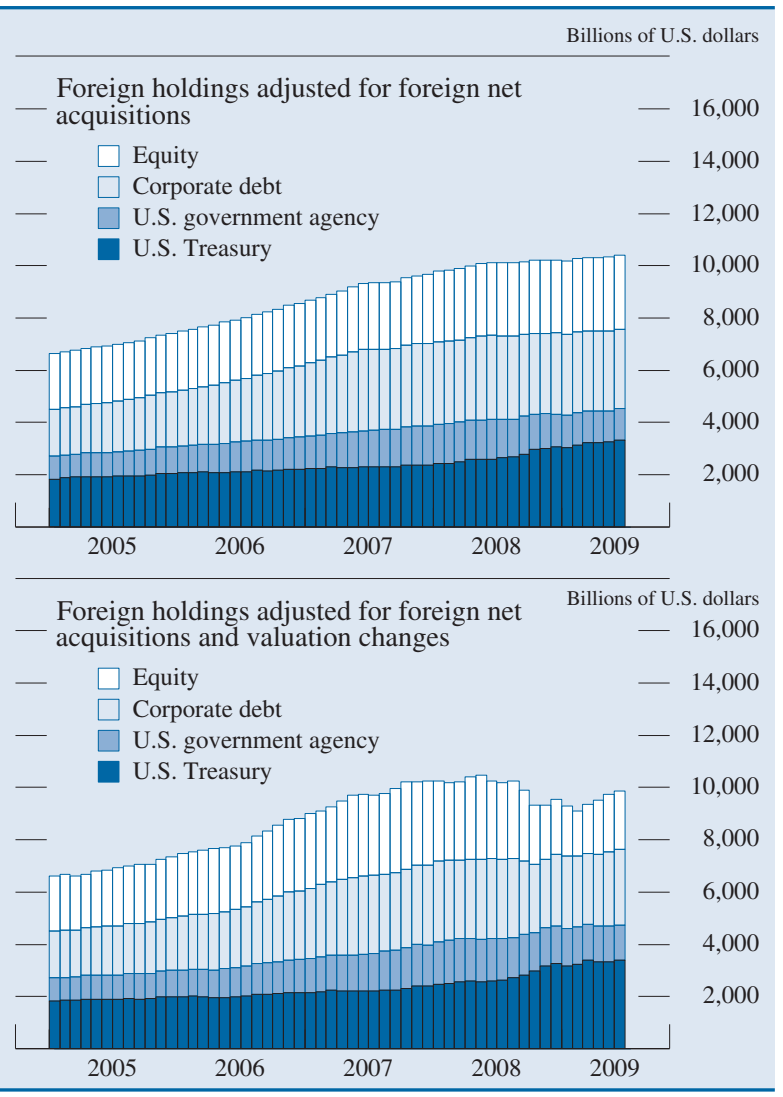

Note: Data extend through June 2009.

\section{Limited Effects of Recent Sales on Overall Cross-Border Securities Holdings}

Although the financial crisis had a marked effect on the composition of securities flows, the size of crossborder positions is sufficiently large that the pullback in cross-border securities holdings resulting from the record cross-border securities sales last fall shows up more as a slight flattening out of securities holdings than as an outright reduction in cross-border exposure. Foreign holdings of U.S. corporate equity, corporate debt, and agency securities moved down somewhat in the second half of 2008, but, on net, total foreign holdings of securities other than Treasury securities were little changed from their pre-turmoil levels (figure 17, top panel). And total foreign holdings of Treasury securities rose by a more than offsetting amount, so that total foreign holdings of U.S. securities actually continued to rise slightly through the second half of 2008 and in 2009.

These limited reductions in foreign holdings of U.S. securities are put into perspective when consid-
18. U.S. holdings of foreign securities adjusted for U.S. net acquisitions, and such holdings also adjusted for valuation changes, by type of security, 2005-09

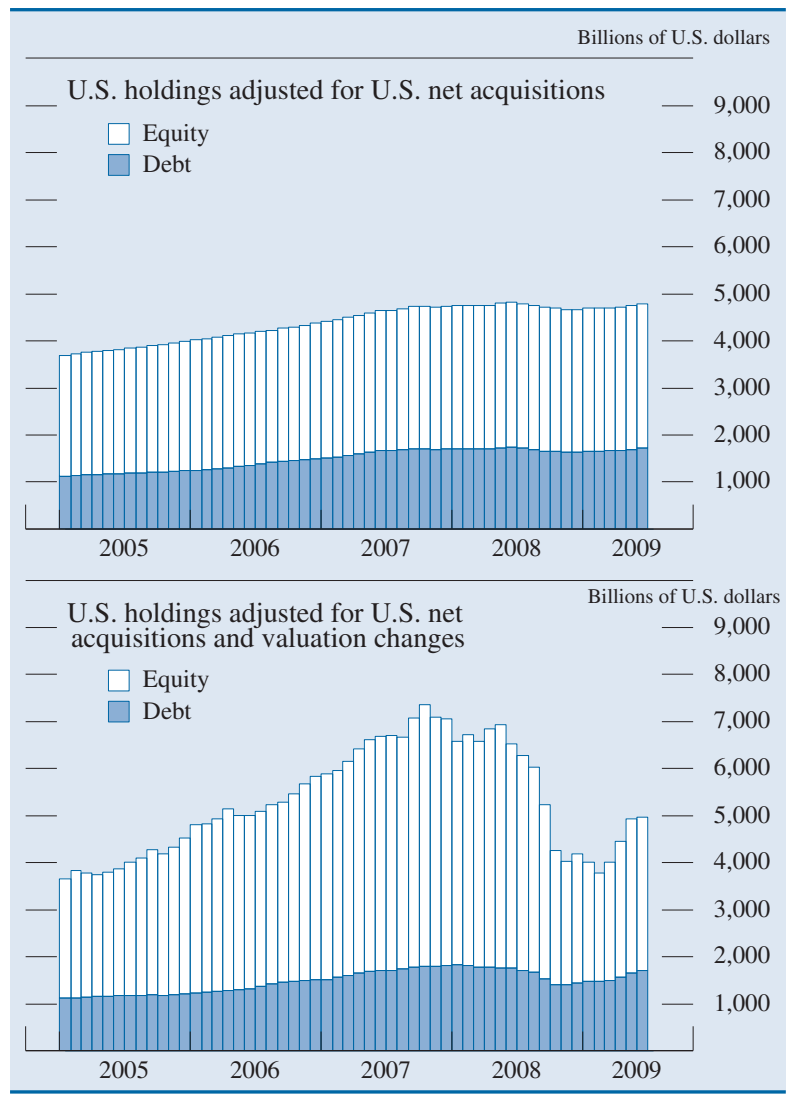

NotE: Data extend through June 2009.

ered in light of the sizable valuation losses foreign investors have faced on their cross-border securities portfolios (figure 17, bottom panel). While foreign net acquisitions of corporate and agency securities left foreign holdings of these securities about unchanged from summer 2007 through year-end 2008, adjusting these holdings by incorporating valuation losses shows a much more pronounced decline. Cumulative valuation losses on foreign holdings of these securities from mid-2007 through the end of 2008 were about $\$ 1.6$ trillion, or roughly 23 percent of their pre-turmoil value. The recovery in equity markets and in corporate bond prices in the first half of 2009, however, reversed about $\$ 200$ billion of these losses.

We provide a similar analysis of the data on U.S. holdings of foreign stocks and debt securities (figure 18). A slight reduction in U.S. holdings resulting from U.S. net sales of foreign securities is evident in the second half of 2008, but this pullback in crossborder positions was just about reversed in the first half of 2009 (figure 18, top panel). However, U.S. 
investors faced considerable valuation losses on their cross-border holdings, especially their holdings of foreign equity in 2008 (figure 18, bottom panel). Total valuation losses are estimated at nearly $\$ 2.5$ trillion, or nearly 40 percent of the value as of June 2007 . Most of these losses are valuation losses on foreign equity, and although foreign equity markets recovered some in the first half of 2009 , we estimate that by June 2009, foreign portfolios of U.S. investors had recovered only to about where they were in early 2006.

\section{Marked Slowdown in Cross-Border Securities Trading}

Although securities positions were little changed by cross-border net sales, gross cross-border trading in U.S. securities was sharply curtailed in the fall of 2008, a further sign of investor caution. In a typical month, total foreign gross purchases and sales of U.S. securities greatly exceed net purchases (figure 19). From 2005 through mid-2007, gross cross-border trading, especially of equities and Treasury securities, grew rapidly, and trading remained at high levels even after the onset of the financial crisis in the summer of 2007. With the intensification of the crisis in October 2008, however, gross trading fell back sharply to the levels last seen in 2005. Trading has been slow to recover but has picked up a bit in recent months, at least with respect to Treasury securities.

\section{Drop-Off in Gross Banking Positions}

In contrast to the limited pullback in securities positions, the decline in cross-border banking positions was substantial. Gross positions declined from their

19. Foreign gross purchases and foreign gross sales of U.S. long-term securities, and foreign net purchases of such securities, 2000-09

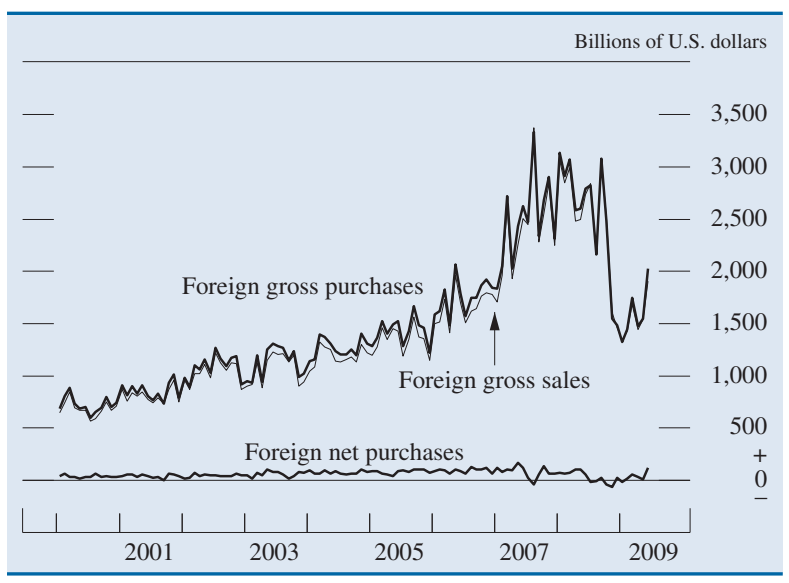

20. Cross-border repurchase agreements, by type of position, 2004-09

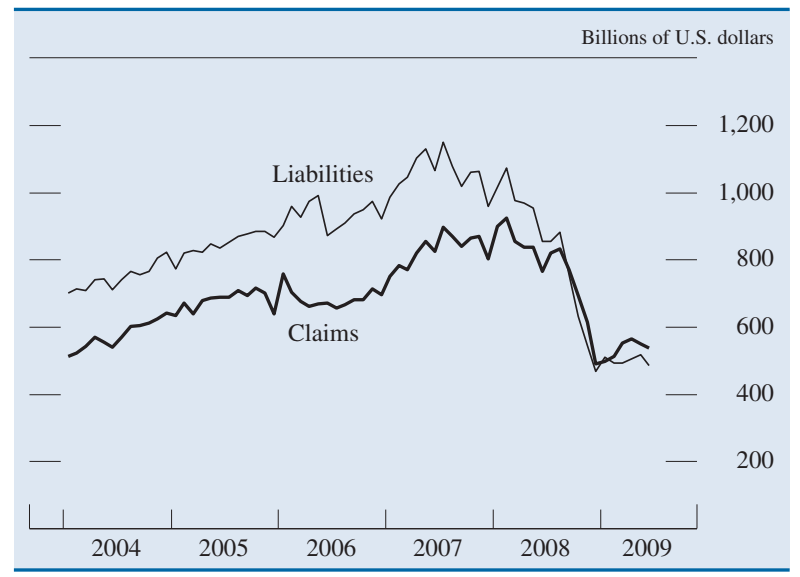

peaks of early 2008 by about 15 percent for claims and 30 percent for liabilities (see figure 10).

A major contributor to the decline in banking positions was the particularly striking drop in repos, an important form of short-term interbank lending (figure 20). Cross-border repos are primarily undertaken by securities brokers (included as reporters in the banking data). The cross-border repo market flattened out in the first three quarters of the crisis but came under further stress with the collapse of The Bear Stearns Companies Inc. in March 2008 as fears about counterparty risk increased. The decline in repos accelerated dramatically with the collapse of Lehman Brothers Holdings Inc. in September 2008. From March through December of 2008, cross-border repo positions shrank 47 percent on the claims side and 57 percent on the liabilities side. Meanwhile, other banking positions fell steeply in September and October of that year as hedge fund liquidations and concurrent declines in derivatives trading contributed to a drop in brokerage balances, which are included in deposits.

\section{Decline in Nonbank Positions}

This section addresses pullbacks in positions, excluding securities and direct investment, of nonbank entities located in the United States (including individuals). ${ }^{10}$ In general, the gross positions of nonbank entities declined during the crisis as firms and investors brought money home, reducing cross-border

10. Positions of nonbank entities are compiled by the Bureau of Economic Analysis (BEA), combining data reported on the TIC system's C form, which collects positions of U.S. nonbank firms with unaffiliated foreigners, with surveys conducted by the BEA, which collect positions with affiliated foreigners, plus additional estimates by BEA staff. 
21. Cross-border loan and bank deposit positions of nonbanks, by type of position, 2006-09

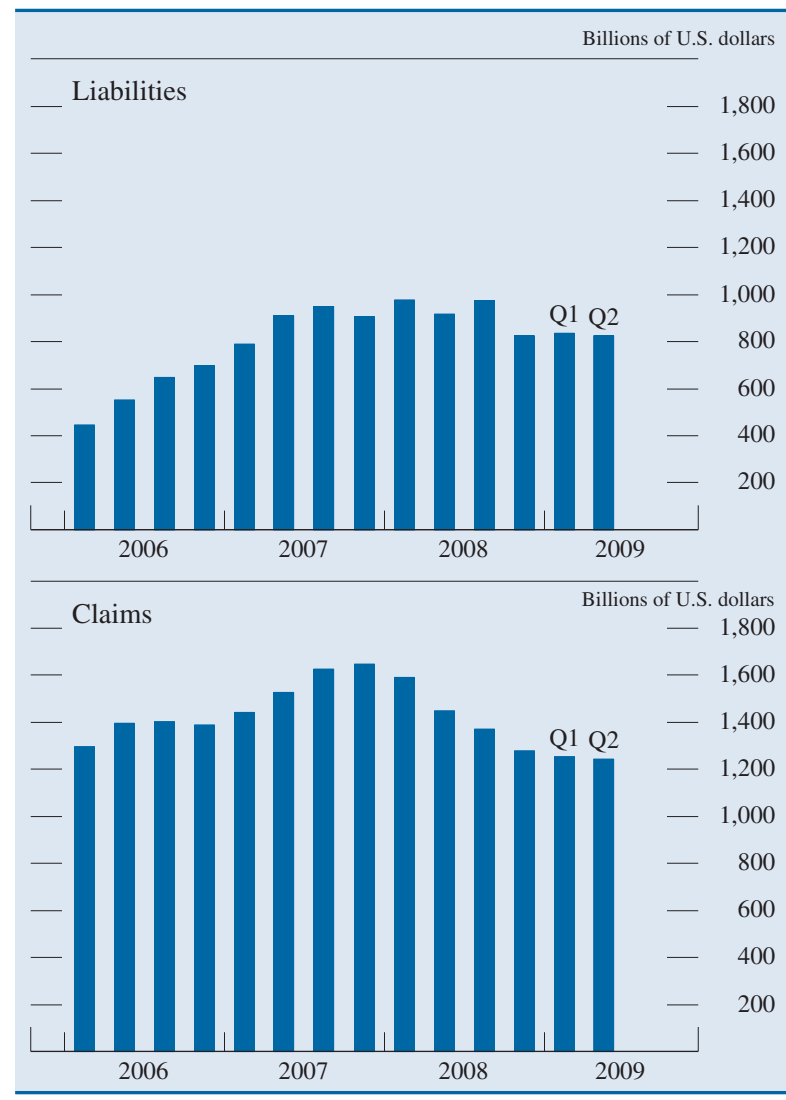

NotE: Liabilities are loans made to U.S. resident firms or individuals by foreigners, mostly foreign banks; claims are loans to foreigners and deposits in foreign banks made by U.S. resident firms or individuals.

SOURCE: Data collected through the Treasury International Capital reporting system, combined with balance of payments data from the Bureau of Economic Analysis.

investments. This decline was a reversal of the trend for both U.S.-residents' investments abroad and foreign investments in the United States. ${ }^{11}$

The decrease is evident in the data on the crossborder loan and bank deposit positions of nonbank firms and individuals (figure 21). ${ }^{12}$ Here, liabilities are loans made to U.S. entities by foreigners, mostly foreign banks (figure 21, top panel). In the other direction, claims are loans to foreigners and deposits in foreign banks made by U.S. entities (figure 21, bottom panel). ${ }^{13}$ Cross-border holdings by nonbanks

11. The decline in foreign holdings of U.S. short-term securities and the decrease in holdings of foreign commercial paper by U.S. residents are discussed earlier in the section "Flight-to-Safety Shifts in Portfolios during the Crisis" (p. A148).

12. The term loans is used broadly to denote other financial positions that are not explicitly securities, negotiable CDs, deposits, direct investment, or commercial (that is, trade).

13. This category includes both positions for which firms use a U.S. bank as a custodian or servicer of their foreign accounts and positions that U.S. firms enter into directly with firms or banks abroad. The of negotiable CDs are also included in this category. Liabilities (loans to the United States) fell about 10 percent in 2008 and a little further in early 2009 . Claims (loans to foreigners and deposits in foreign banks) fell more steeply_almost one-third in 2008.

Cross-border commercial positions also exhibited declines. These positions are primarily trade payables and advance receipts (liabilities) and trade receivables and advance payments (claims). The gross level of commercial positions (not shown) declined about 10 to 20 percent in the second half of 2008 with the fall in trade and the tightness of trade financing.

Cross-border positions of financial intermediaries that are neither banks nor securities brokers also fell dramatically during the crisis. ${ }^{14}$ However, as with securities, the financial crisis exacerbated or highlighted difficulties in measuring certain nonbank financial flows. This circumstance was particularly true for positions of the many financing vehicles that were not full-fledged firms in the sense of having employees or physical headquarters. During the crisis, the Bureau of Economic Analysis discovered that many SPVs or SIVs located in offshore financial centers had affiliated vehicles in the United States that issued securities and loaned the proceeds to the offshore entities. ${ }^{15}$ Such direct loans are difficult to survey. The size of the cross-border position resulting from these loans is estimated by the amount of securities issued by the vehicles known to have this structure. When markets for ABCP froze in the fall of 2007, the U.S. vehicles were unable to roll over short-term debt securities. To pay off maturing securities, the U.S. vehicles had to reclaim the funds they had loaned to the offshore entities, thereby creating an inflow of $\$ 170$ billion in the second half of 2007 and a significant decline in the level of cross-border claims. Overall, as markets deleveraged and some vehicles ceased to exist, cross-border claims fell nearly 40 percent, and liabilities about 23 percent, from their peaks in 2007 (figure 22).

positions that use a U.S. bank as a custodian are reported in the TIC data and are included in the financial account as positions reported by banks. The positions held directly with foreign counterparties are not included in the TIC data; in the financial account, these are positions with unaffiliated foreigners reported by U.S. nonbanking concerns.

14. Examples of such entities include insurance firms, financial management firms, and securitization vehicles.

15. Intercompany positions are generally considered direct investment, which is not discussed in this article, except for non-equity positions between financial firms such as banks, securities brokers, and financing vehicles. 
22. Cross-border positions of nonbank financial intermediaries, by type of position, 2006-09

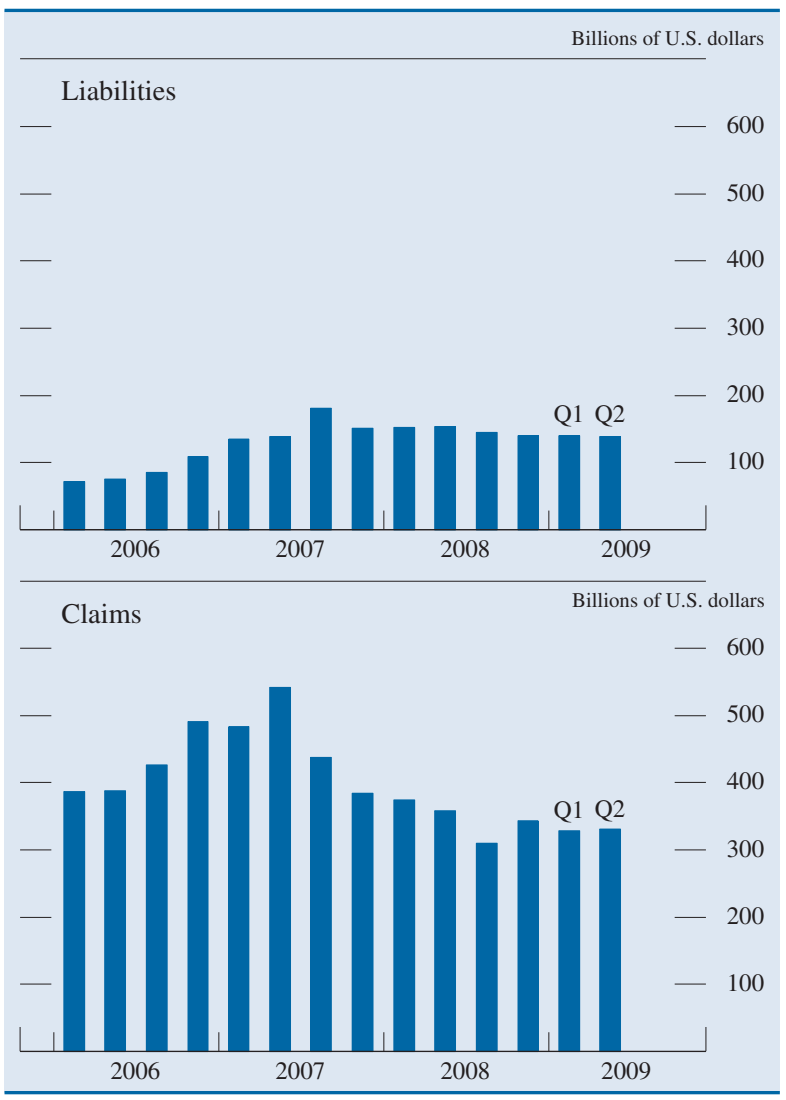

NotE: The majority of these claims and liabilities are in the form of intercompany balances. Such balances represent transactions between firms in a direct investment relationship, but the transactions are excluded from direct investment data when both firms are classified in the finance industry, and they are excluded from banking data when the firms are neither banks nor securities brokers.

SOURCE: Bureau of Economic Analysis.

\section{CONCLUSION AND GLOBAL OVERVIEW: SIMILAR PORTFOLIO SHIFTS IN OTHER COUNTRY STATISTICS?}

U.S. cross-border financial flows indicate pronounced flight-to-safety swings in the composition of securities purchased during the financial crisis, with foreign investors, on net, selling U.S. securities other than U.S. Treasury securities and U.S. investors, on net, selling foreign securities, especially in the second half of 2008. We look next to see whether such shifts in cross-border securities purchases are also evident in financial flow data for the euro area, the United Kingdom, and Japan. And although we did not see much evidence of a pullback in cross-border securities investment relative to the size of cross-border holdings in the U.S. data, we consider whether data for these countries indicate a global pullback in investment in securities other than those of the home country of the investor.

Similar to the pattern of cross-border investment for U.S. investors, investors in both the euro area and the United Kingdom had made sizable and growing cross-border securities purchases in the years leading up to the financial turmoil. In both regions, home investors also reduced their net purchases of "foreign" securities (that is, securities issued outside of the home country) following the onset of the crisis in 2007 and made large net sales of such securities in the second half of 2008 (figure 23, top and middle panels). As financial markets stabilized more recently, these net sales again reversed to show net purchases, though the reversal through June 2009 is relatively small for the euro area. Financial flow data for Japan, however, do not show a similar pullback from foreign investment (figure 23, bottom panel). Instead, Japanese investors acquired increasing amounts of foreign securities through the first half of 2008, suggesting that the financial crisis may have affected U.S. and European investors sooner and to a greater extent than it did Asian investors. And although global equity prices fell sharply in the second half of 2008, Japanese investors increased their purchases of foreign equity, though they did reduce their purchases of foreign bonds.

We also look at foreign investment in the euro area, the United Kingdom, and Japan to see if the data for these countries show patterns similar to that for the United States - that is, reduced foreign purchases of riskier securities issued by these countries. The pattern of a flight to safety by foreign investors does seem to be present in the euro-area data: We see a marked slowdown in purchases of euro-area equities by foreign investors during the onset of the crisis in the second half of 2007 and a shift to large sales of euro-area equity during the intensification of the crisis in the second half of 2008 (figure 24, top panel). The euro-area data also show reduced foreign purchases of euro-area bonds, especially in the second half of 2008. Detail underlying this slowdown indicates offsetting purchases of euro-area sovereign bonds and sales of other, presumably riskier, euroarea debt securities. In contrast, foreign inflows into money market instruments jumped sizably in the second half of 2008. These inflows, concentrated in September and October of 2008, were mostly in the form of increased foreign purchases of short-term euro-area government securities, consistent with foreign investor demand for safer or more-liquid investments during the intensification of the financial crisis. The Japanese data also suggest flight to safety, as they 
23. Cross-border portfolio investment: Domestic net acquisitions of foreign securities for the euro area, the United Kingdom, and Japan, by type of security, 2002-09

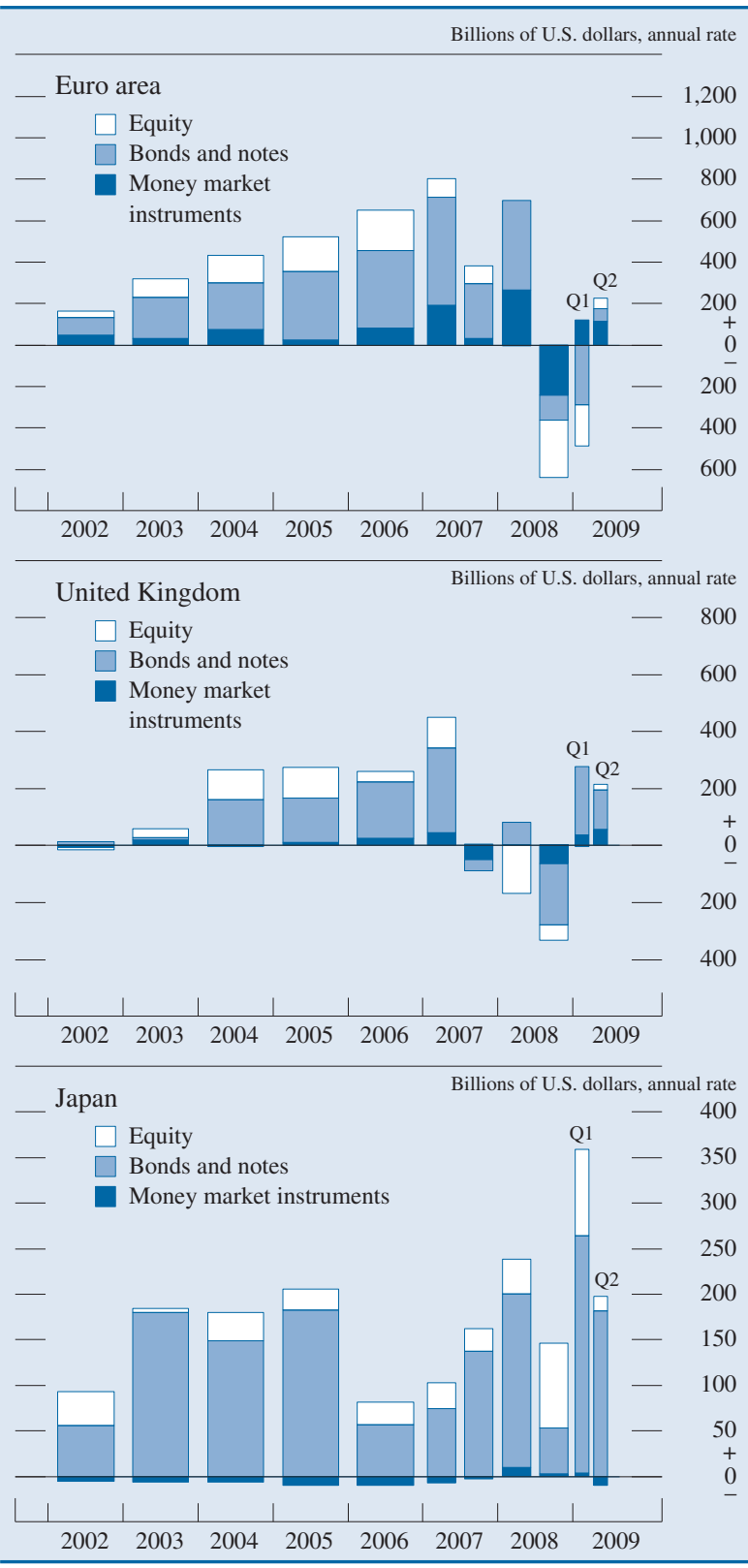

Note: See general note to figure 1.

SOURCE: Staff estimates from balance of payments accounts as reported by the European Central Bank, U.K. Office for National Statistics, and Bank of Japan via Haver Analytics.

show net sales of Japanese equity and large inflows into liquid money market instruments beginning in the summer of 2007 and then a switch to net sales of all types of Japanese securities by foreign investors in the second half of 2008 (figure 24, bottom panel).

Evidence of such flight-to-safety flows is less apparent in the U.K. data, as foreign purchases of
24. Cross-border portfolio investment: Foreign net acquisitions of domestic securities for the euro area, the United Kingdom, and Japan, by type of security, 2002-09

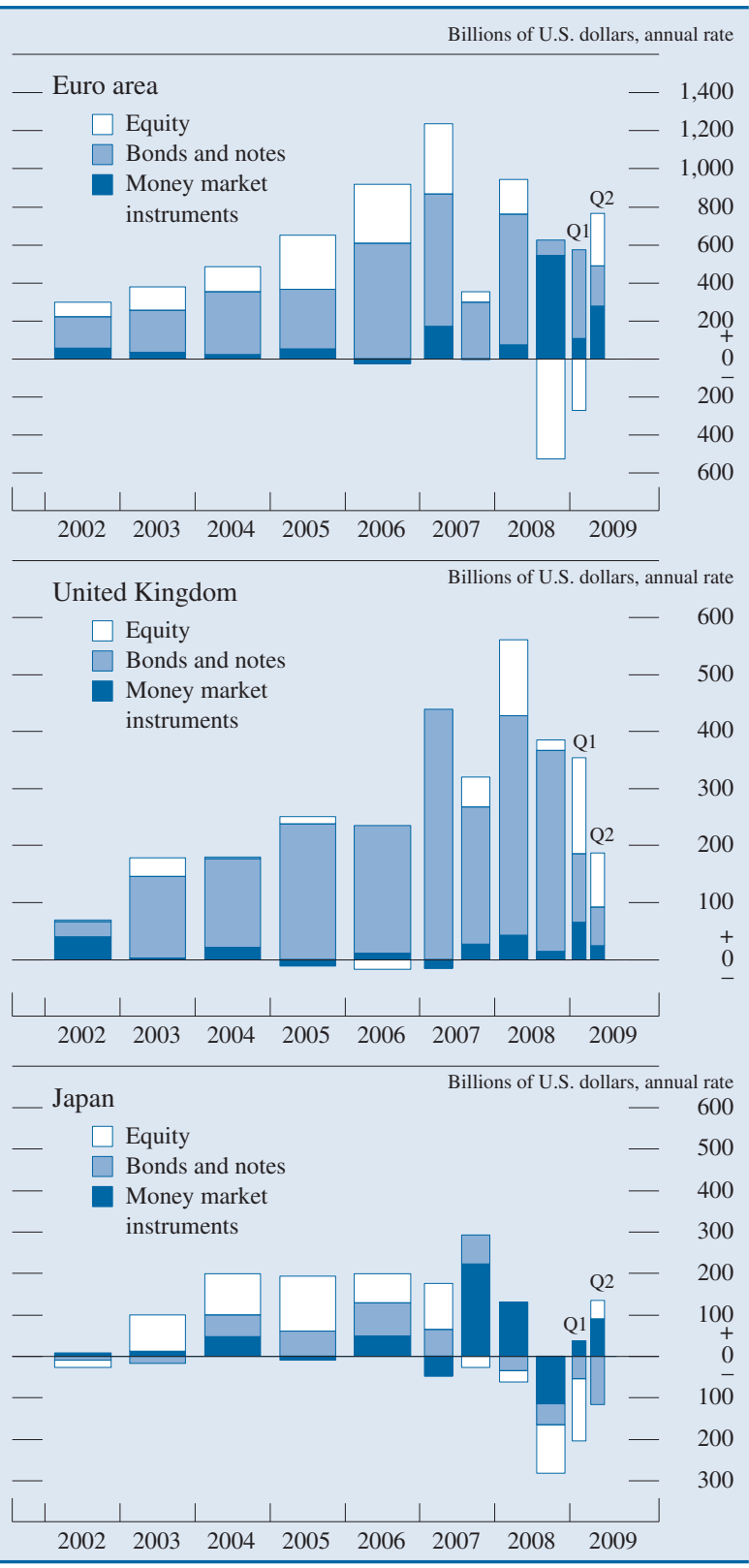

NoTE: See general note to figure 1 .

SOURCE: Staff estimates from balance of payments accounts as reported by the European Central Bank, U.K. Office for National Statistics, and Bank of Japan via Haver Analytics.

U.K. equity appear to have been less influenced by market swings (figure 24, middle panel). The U.K. data also indicate continued strong foreign purchases of long-term U.K. debt securities, even in the second half of 2008. However, detail underlying these figures shows a shift in the composition of foreign purchases that is similar to the shift evident in the euro-area data: 
25. Cross-border portfolio investment: Domestic holdings of foreign securities adjusted for domestic net acquisitions for the euro area, the United Kingdom, and Japan, and such holdings also adjusted for valuation changes, 2005-09

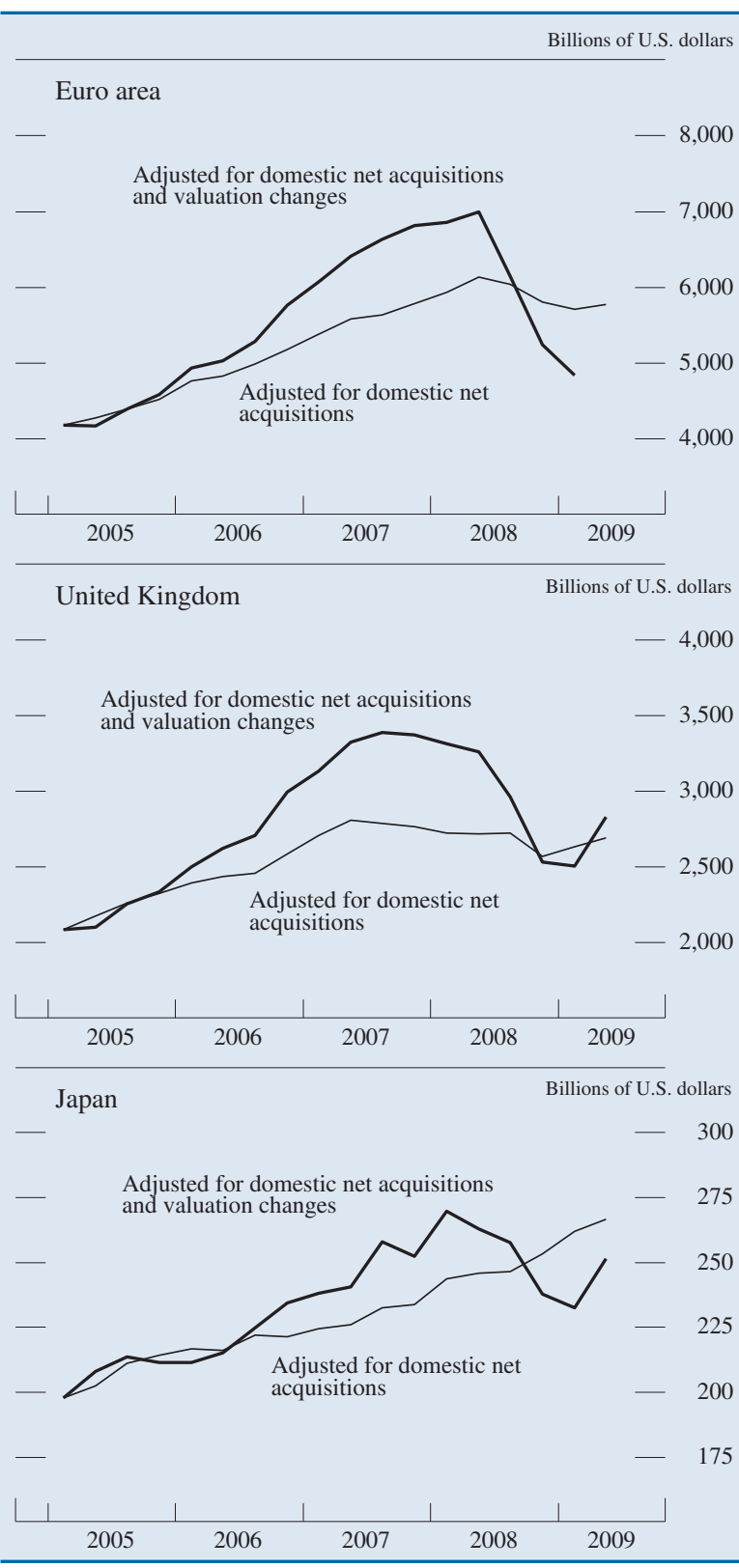

SOURCE: Staff estimates from international investment positions and balance of payments accounts as reported by the European Central Bank, U.K. Office for National Statistics, and Bank of Japan via Haver Analytics.

Foreign investors' purchases of U.K. government securities picked up in the second half of 2008, while their purchases of debt securities issued by financial institutions fell sharply and remained weak in the first half of 2009.

But as with the U.S. data, these effects on the composition of cross-border financial flows in other
26. Cross-border portfolio investment: Foreign holdings of domestic securities adjusted for foreign net acquisitions for the euro area, the United Kingdom, and Japan, and such holdings also adjusted for valuation changes, 2005-09

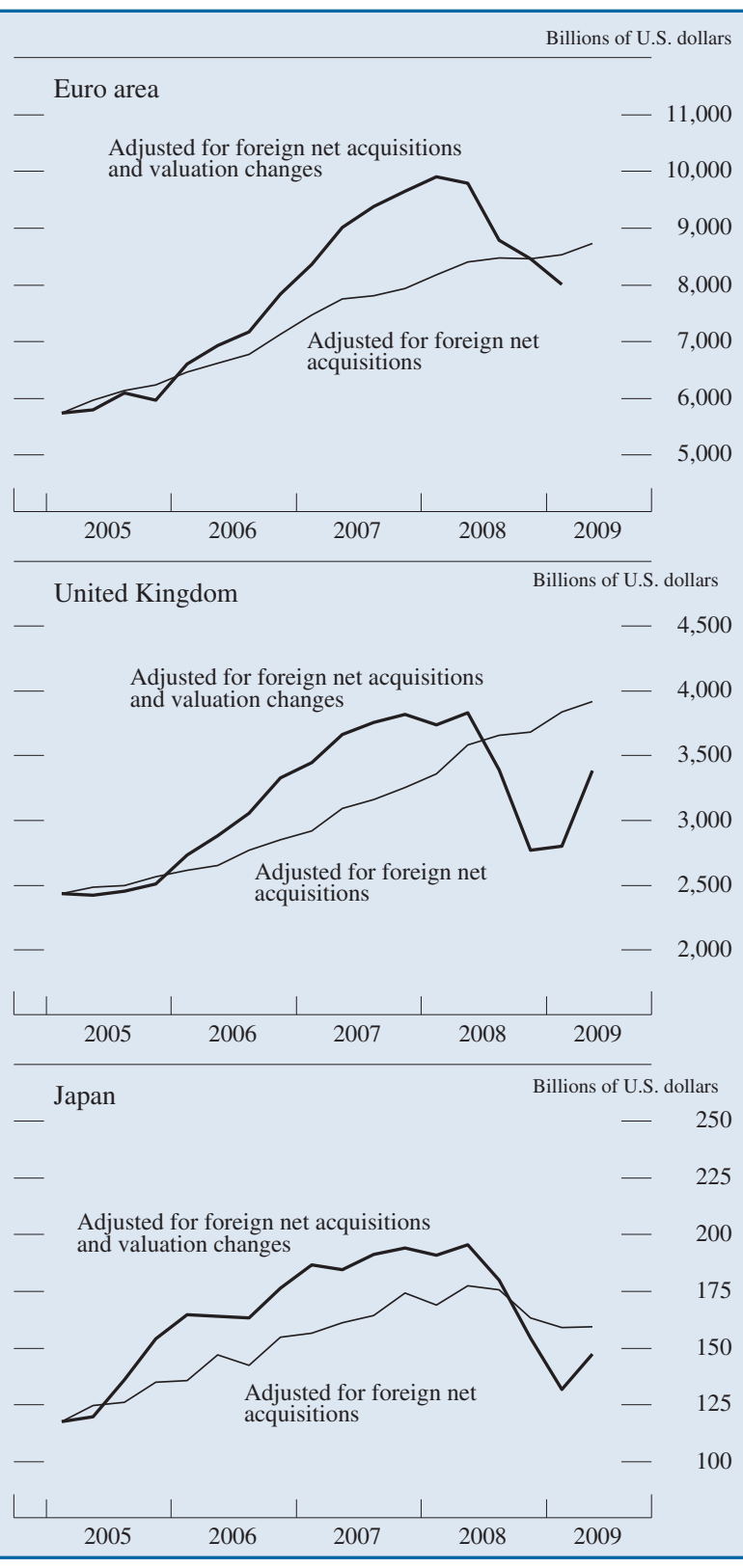

SoURCE: Staff estimates from international investment positions and balance of payments accounts as reported by the European Central Bank, U.K. Office for National Statistics, and Bank of Japan via Haver Analytics.

industrial countries do not indicate a significant pullback in the overall size of such countries' crossborder securities positions (figure 25). In the euro area and the United Kingdom, recent reductions in holdings of foreign securities arising from sales of foreign securities (thin lines) are small relative to the size of holdings and compared with the actual move- 
ments in investment positions incorporating valuation changes (thick lines). And the reduction in foreign holdings of Japanese securities arising from foreign sales of such securities since mid-2008 also is quite small, especially relative to valuation losses incurred on these holdings (figure 26).

Similarly, the fall in cross-border banking activity evident in the U.S. data was mirrored by declines in banking activity around the globe. The external (that is, cross-border) claims of all banks located in countries reporting to the Bank for International Settlements fell about 8 percent between March and December of 2008. ${ }^{16}$ Declines early in the year were concentrated in the United States and the United Kingdom, but in the fourth quarter, sizable drops occurred in the euro area, developing countries, and offshore financial centers as well.

With the improvement in the tone of financial markets so far in 2009, many of the unusual crossborder financial flows generated by the financial crisis appear to be reversing. U.S. and foreign data indicate

16. See the figure "Cross-border positions" in Bank for International Settlements (2009), BIS Quarterly Review, "Statistical Annex," table 1A (Basel, Switzerland: BIS, June), p. A4, www.bis.org/publ/ qtrpdf/r_qs0906.pdf. that investors are making renewed purchases of riskier foreign securities such as equities and that purchases are no longer concentrated in safer and more-liquid short-term government debt securities. Increased cross-border interbank lending and the concurrent decline in central bank swaps indicate that banks are again able to provide funding through interbank markets. However, cross-border data to date also indicate some longer-lasting effects of the financial crisis. The slow recovery in interbank repo positions and still-subdued gross cross-border securities trading suggest continued investor caution. Moreover, many of the institutions directly affected by the crisis-SPVs and SIVs active in the issuance of ABS - were located in offshore financial centers, and the unwinding of their activity and the closure of some of these entities have had a notable effect on the size of nonbank cross-border positions. And because much of the pre-crisis growth in cross-border purchases of corporate debt securities was in the form of corporate ABS, the disruption in corporate ABS markets and the curtailment of corporate ABS issuance show through as significantly reduced foreign purchases of corporate debt securities. 